برآورد يارامترهاى زنتيكى برخى صفات مورفولوزيكى كندم دوروم (Triticum turgidum L.) ديم با استفاده از روش داى آلل هيمن

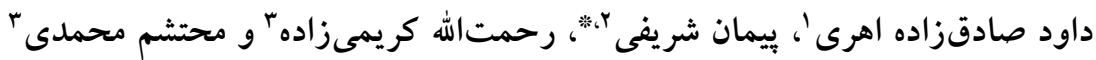

$$
\text { 1- استاديار، موسسه تحقيقات كشاورزى ديم كشور، مراغه }
$$

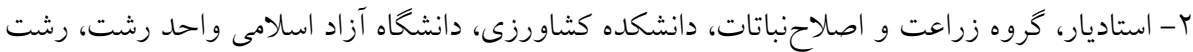

ب- استاديار، موسسه تحقيقات ديم كشور، گُخساران

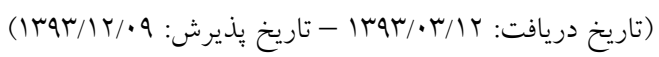

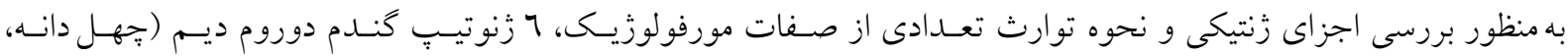

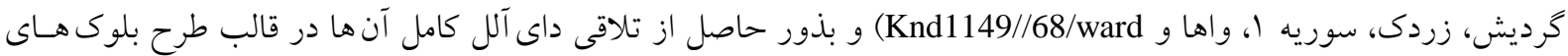

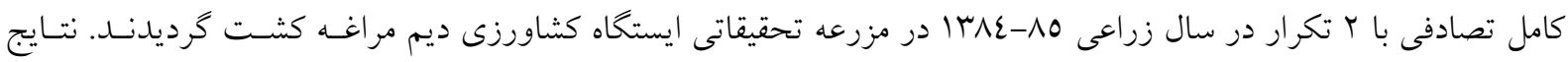

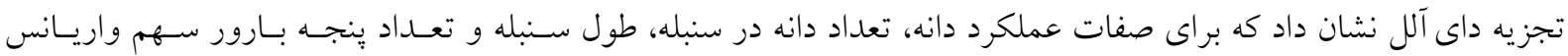

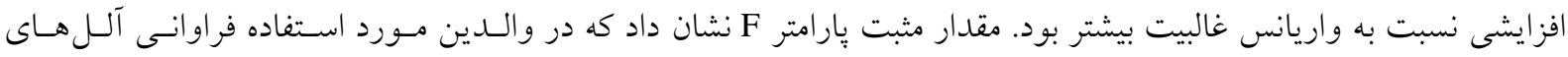

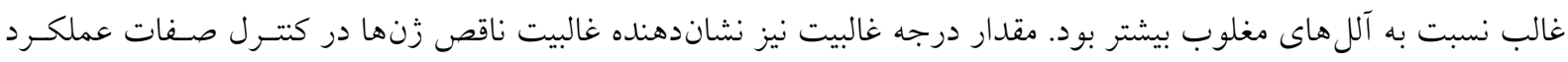

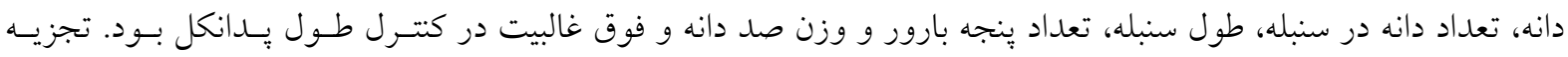

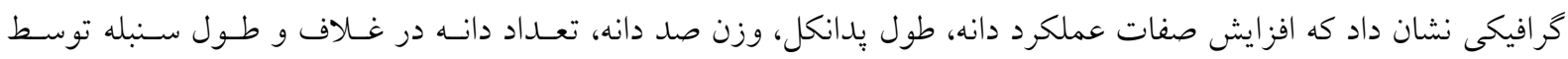

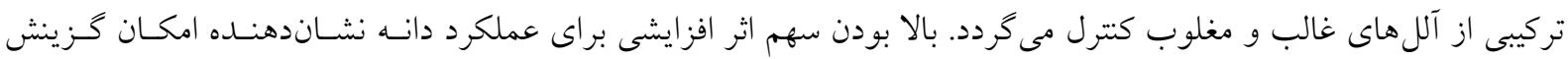

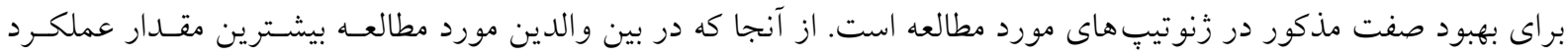

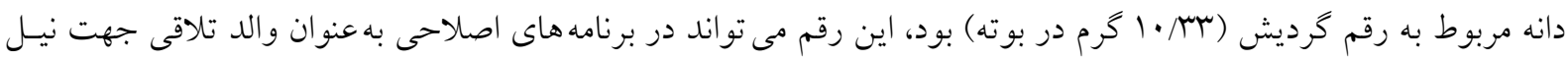

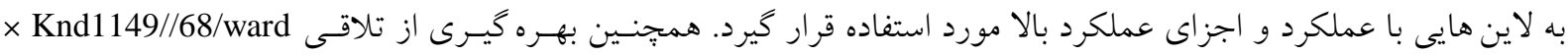
و اها با بيشترين ميزان عملكرد در بين زنوتيٍهاى مورد مطالعه، در برنامهاى توليد هيبريد توصيه مى تشود. واز كان كليدى: اثر افزايشى، اثرغير افزايشى، تجزيه كرافيكى، گندم دوروم، غالبيت 
عملكرد دانه تكى بوتـه كنــدم نـان نقـش مهـم تـرى دارد.

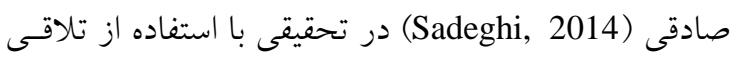

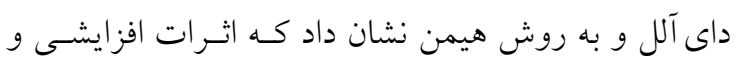

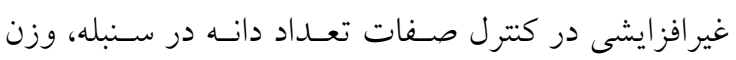

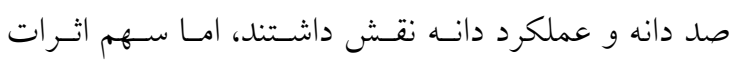
افزايشى براى وزن هزار دانه بيشتر بود، در حالى كه بـراى داى دان

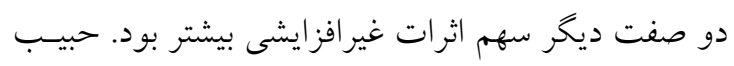

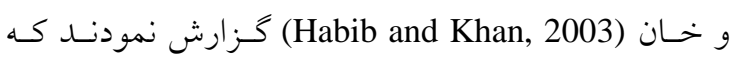

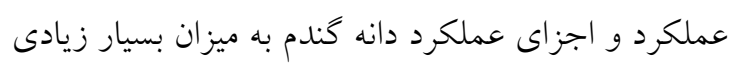

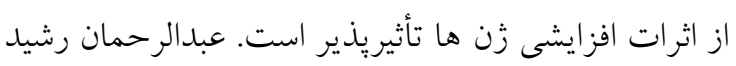

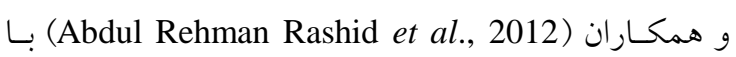
استفاده از ينج رقم كُندم نان و روش نيمـه دى آلـل نشـان دادند كه صفات تعداد يُنجه در بوته، طـول سـنبله، تعـداد دانه در بوته به وسيله اثرات افزايشى و غالبيت نسبى كنترل

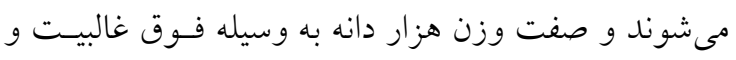

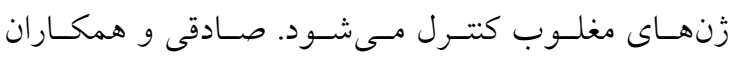

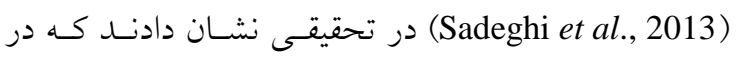
كُندم نان سـهم اثـر افزايشـى در كنتـرل وزن هـزار دانـه،

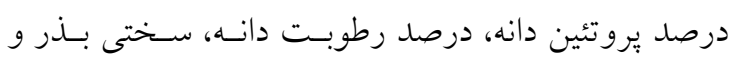

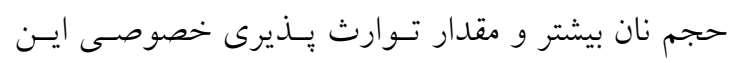

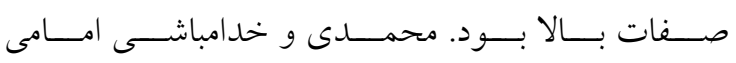
در (Mohammadi and Khodambashi Emami, 2008) تحقيقى با توجه به برآوردهاى ميـانخين درجـه غالبيـت و و

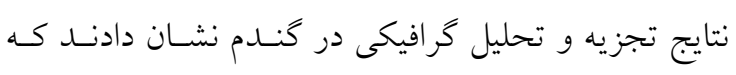

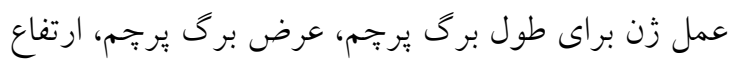

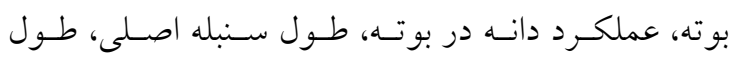

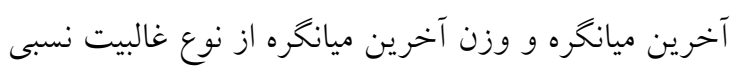
بود. همجنين در تحقيقـات ديخــرى جـودرى و همكـاران Malik (Chowdhry et al., 2005)

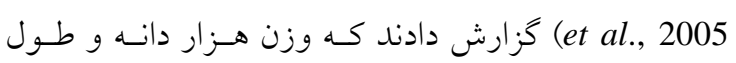

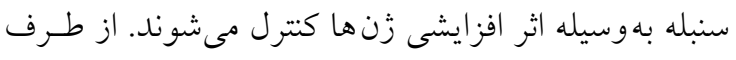

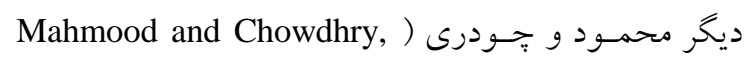

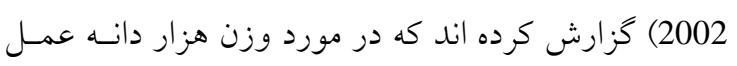

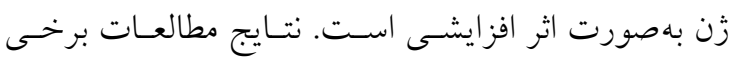

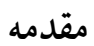

Triticum turgidum Var. durum, كنـــــم دورومم،

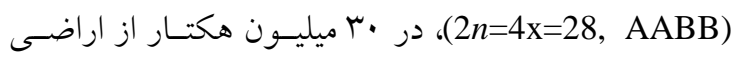
كشاورزى جهان كاشته مى شود و حدود · ا درصد از توليد جهانى گندم را به خود اختصاص مىدهد (FAO, 2013).

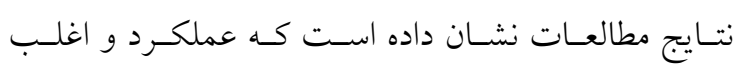
صفات مرتبط با آن از قبيل تعـداد ســبله، تعـداد دانـه در

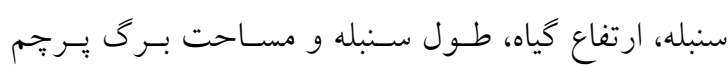
صفات كمّى بيّيجيده اي هستند و توسط تعـداد زيـادى زن كنترل شده و تحت تأثير محيط قرار مسى كيرنسـ ( Verma

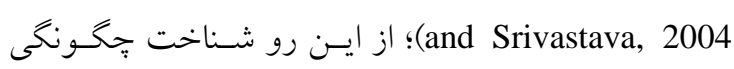
توارث و ارزيابى هيارامترهـاى زنتيكسى كتــرل كنـــده ايسن صفات در اصلاح آن ها از اهميت زيادى برخوردار اسـت.

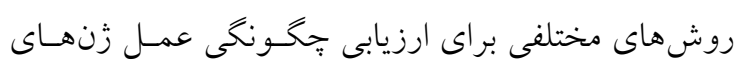

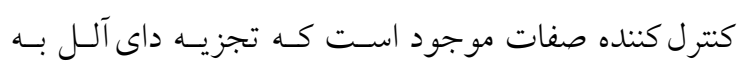
روش هيمن (Hayman, 1954 b) يكى از رايجترين آنهـا است.

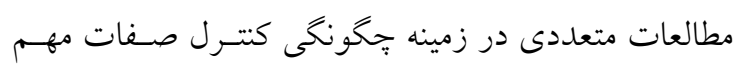
مورفولوزيكى در كندم به روش هيمن و همجنــين تجزيسه Vر افيكى انجام بذيرفته اسـت. ونـدا و هوشـمند ( Vanda (and Houshmand, 2011 صفات تعداد ينجه بارور، تعداد دانه در سـنبله و عملكـرد

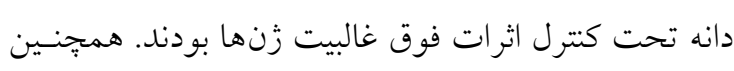
در مورد اين صفات، اثرهاى افزايشى و غالبيت زنى داراى

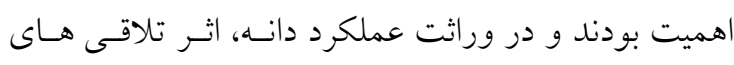
Heidari et (معكوس نيز معنى دار بود. حيدرى و همكار

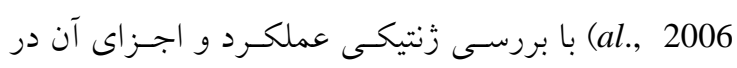

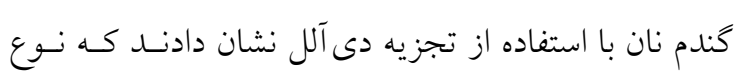

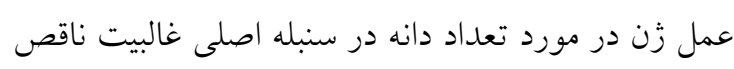

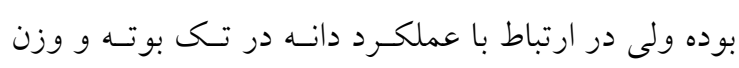

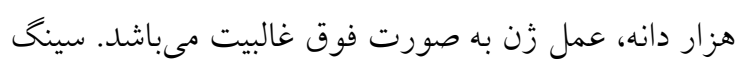

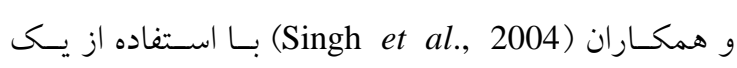
آزمايش داى آلل نشان دادند كه اثر غير افزايشـى زنهـا در

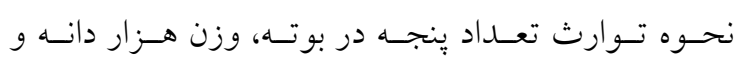


مورد مطالعه قرار داشتند (جدول (). در سال زراعى 10-عیىا نتاج حاصله به همراه والدين (جس تيمار) به صـورت

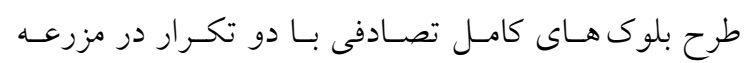

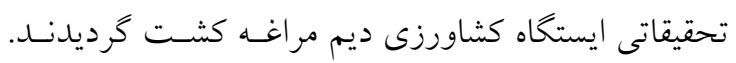
هر كرت آزمايشى شامل ع خط كاشت بـه طـول ع متـر و فواصل خطوط ·r سانتىمتر بود. ضمن انجام عمليـات مربـوط بـه مرحلـه داشـت (وجــين

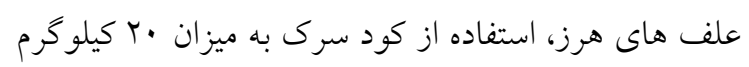
در هكتار در اوايل مرحله ينجهزنى و به هنخام اطمينـان از

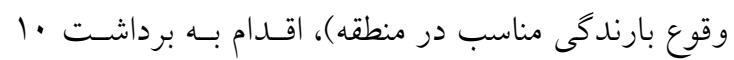

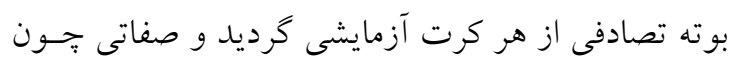
تعداد ينجه بارور، عملكرد دانه، طول سنبله، تعداد دانه در سنبله، طول يدانكل و وزن صد دانه يادداشتبردارى شد.

$$
\text { جدول 1- فهرست والدين مورد استفاده در انجام }
$$

\begin{tabular}{|c|c|c|c|}
\hline $\begin{array}{l}\text { شماره } \\
\text { No. }\end{array}$ & $\begin{array}{c}\text { زْنوتيتِ } \\
\text { Genotype }\end{array}$ & $\begin{array}{c}\text { عادت رشد } \\
\text { Growth habit }\end{array}$ & $\begin{array}{l}\text { وضعيت اصلاحى } \\
\text { Breeding Status }\end{array}$ \\
\hline \multirow{2}{*}{1} & جִهل دانه & زمستانه & رقم بومى \\
\hline & $\begin{array}{l}\text { Chehel } \\
\text { daneh }\end{array}$ & Winter & Land race \\
\hline \multirow{2}{*}{2} & كرديش & زمستانه & رقم بومى \\
\hline & Gerdish & Winter & Land race \\
\hline \multirow[t]{2}{*}{3} & زردى & بينابين & رقم ا \\
\hline & Zardak & Facultative & Improved cultivar \\
\hline \multirow[t]{2}{*}{4} & سوريه 1 & بهاره & لاين \\
\hline & Syrian-1 & Spring & Line \\
\hline \multirow[t]{2}{*}{5} & واها & بهاره & رقم اصلاحى \\
\hline & Waha & Spring & Improved cultivar \\
\hline \multirow[t]{2}{*}{6} & $\begin{array}{c}\text { Knd1149// } \\
\text { 68/ward }\end{array}$ & بينابين & لاين \\
\hline & & Facultative & Line \\
\hline
\end{tabular}

Table 1. List of parents in diallel cross

تجزيه واريانس و مقايسه ميانخين ها بـه روش حـــاقل اختلاف معنى دار در سطح احتمال 0 درصد بـا اسـتفاده از نرم افزار SAS انجام كرفت. تجزيه واريانس بـراى دادههــا

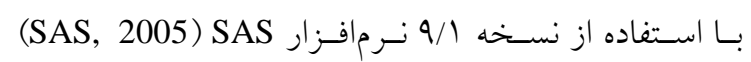
صورت گرفت. براى صفاتى با F معنى دار براى زنوتيٍِ ها و نيز صادق بودن فرض هاى مدل، تجزيه دى آلل به روش

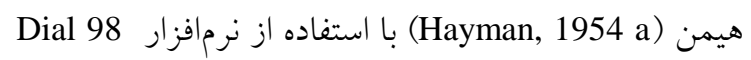
انجام شـــ. در ايسن راسـتا، آزمسون اثـرات (Ukai, 2006)
يخزوهشخران نشان مى دهد كه اثر غير افزايشـى و اثـر فـوق غالبيت در كنترل طول سنبله، تعـداد سـنبلجه در سـنبله و

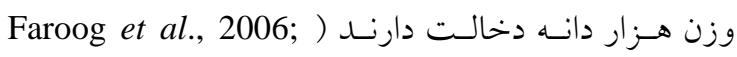
Nazeer et al., (Rahim et al., 2006 2011) در مطالعـهاى در گنــدم نـان نشـان دادنـــ كــه اتـر افزايشى براى صفات طول سنبله، تعداد سنبلهُه بر سـنبله، تعداد دانه در سنبله، وزن دانـه در سـنبله و عملكـــد دانـه معنى دار بود، اما در كنترل زنتيكى عملكـــد دانـه و طـول سنبله عمل غالبيت زن ها نقـش مهــم تـرى داشـت. ايشـان همجنين وراثت يذيرى خصوصى بـالايى را بـراى تعـداد

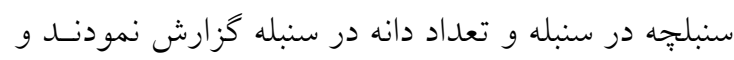
براى صفات طول سنبله و عملكـــد دانـه فـوق غالبيـت و براى صفات تعداد دانه در سنبله و تعداد سنبلجه در سنبله اثر افزايشى زن و غالبيت ناقص را نشان دادند. ال حمدانى (Al-Hamdany, 2010) كُندم دوروم نشان داد كه عملكرد دانه در اين ارقام تحـت Kنترل عمل افزايشى زن است. خان و همكاران ( Khan et (al., 2000 در يـك تلاقـى داى آلـل 0 × 0 در گنــدم نـان نشان دادند كه صفات ارتفاع بوته، طول يدانكل و عملكرد دانه تحت كنترل عمل افزايشى زن با غالبيت جزئسى قـرار

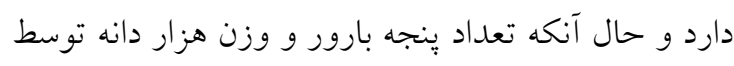
عمل غالبيت زنها كنترل مىشود. تحقيق حاضر به منظور مطالعه صفات مورفولوزيكى و

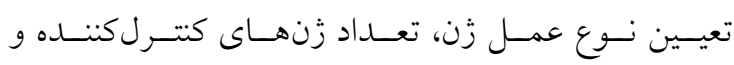
وراثت يذيرى در زنوتيِّ هاى مورد بررسى و نتاج حاصـل از تلاقى داى آلل كامل آنها طراحى و اجرا گرديد.

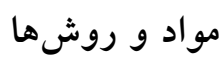

در اين يزوهش، به طور تصادفى از بين ارقام و لايسـنهـاى

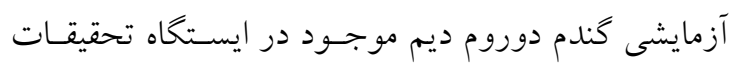
كشاورزى ديم مراغه، شش زنوتيبٍ (شامل تعدادى لاين و رقم) انتخاب و براى تشكيل يك مجموعسه دى آلـل، تمـام

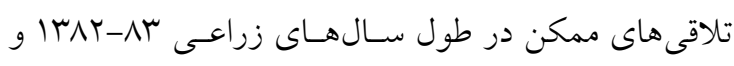

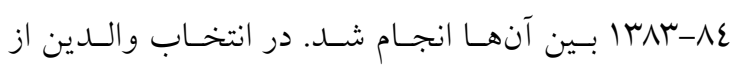
زنوتيٍّ هايى استفاده شد كه در دو دامنه متفاوت از صفات 
مورد مطالعه برابر با ع/ ب بوده و كمترين تعداد آن برابر با

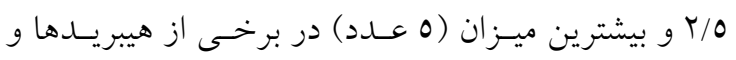

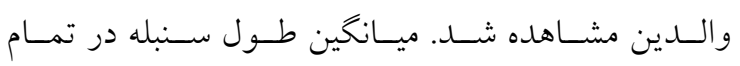

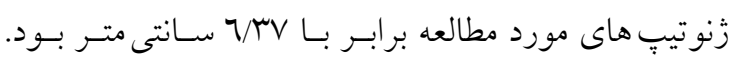

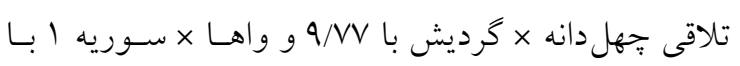

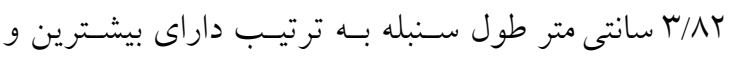

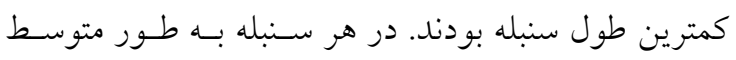

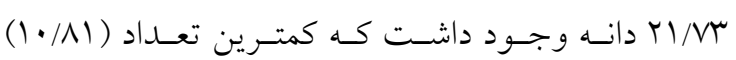
مربوط به والد زردى و بيشترين تعداد مربسوط بـه دورى

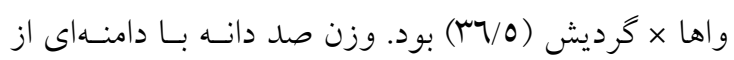

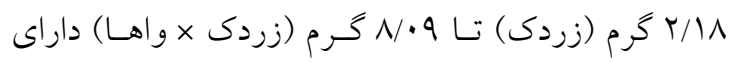

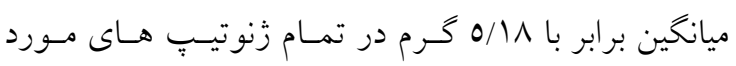

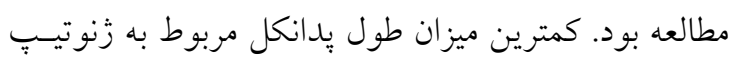

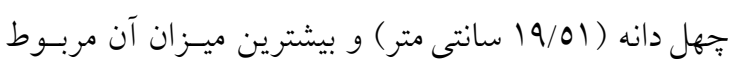

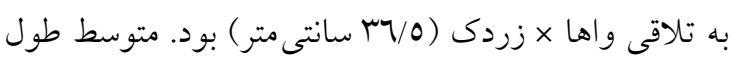

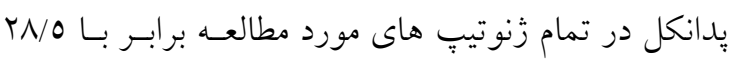

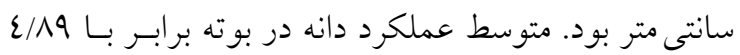

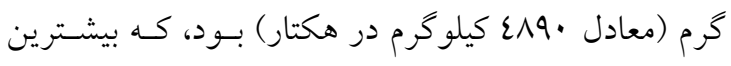

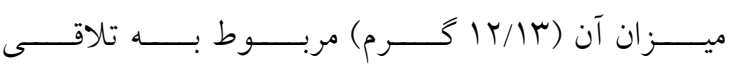

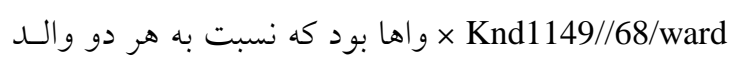
خود برترى معنى دارى داشـت. همجنهـين كمتـرين ميـزان

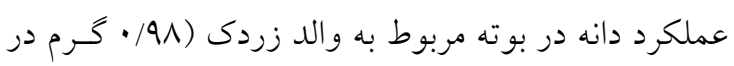
بوته) بود.
اييسـتازى بـا اسـتفاده از آزمـون شـيب خـط ركرسـيون

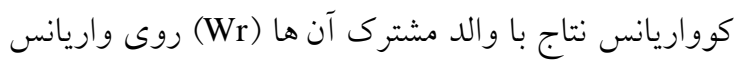

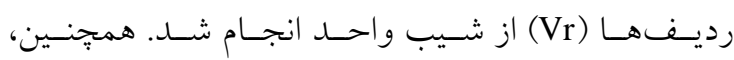

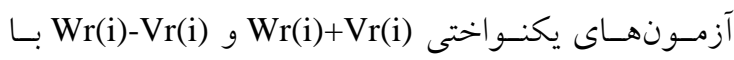

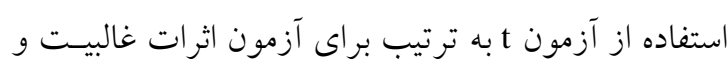
إييستازى صـورت كرفـت (Mather, and Jinks, 1985).

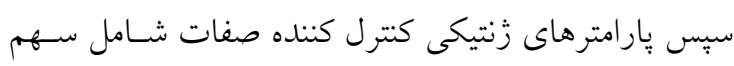
واريانس هاى افزايشى و غالبيت و درجه غالبيت هر يكى از

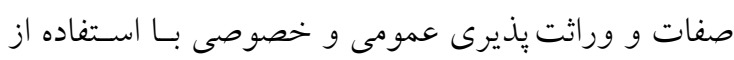

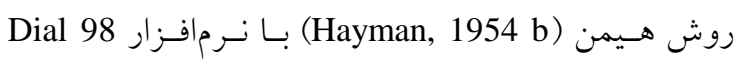
بر بر آورد شدند.

\section{نتايج و بحث}

نتايج حاصل از تجزيه واريانس، حساكى از وجـود تفـاوت

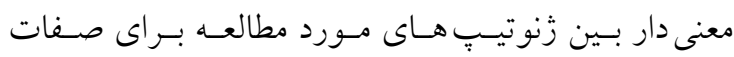

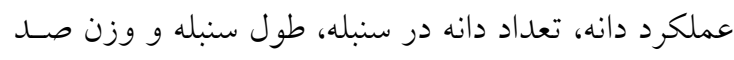

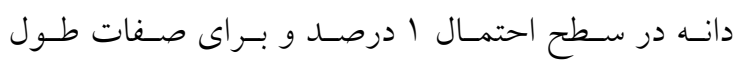

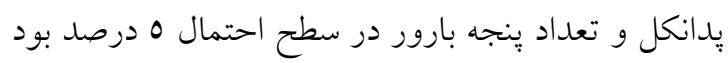

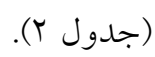
مقايسه ميـانخين صـفات مـورد مطالعـه بـا اسـتفاده از

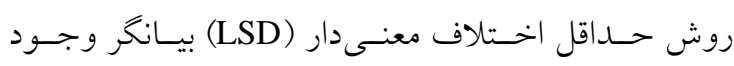

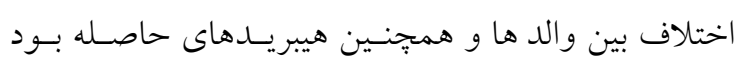

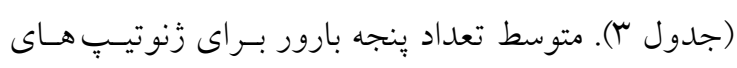

جدول r- تجزيه واريانس صفات مورد مطالعه در خندم دوروم

Table 2. Analysis of variance for some traits in durum wheat

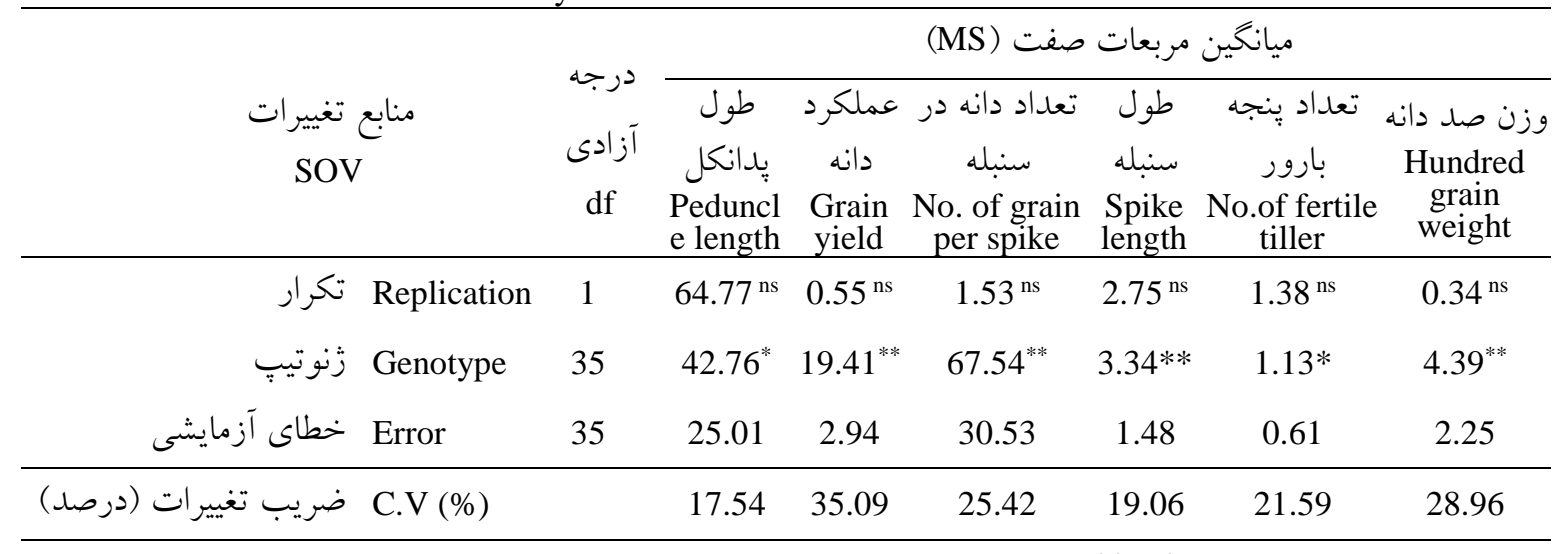

ns

ns, * and ${ }^{* *}$ : Not significant, significant at $5 \%$ and $1 \%$ probability levels, respectively. 


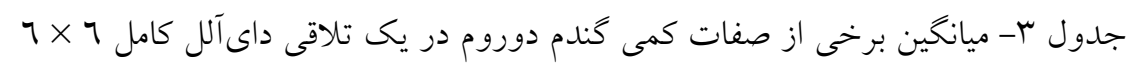

Table 3. Means of some quantitative traits in a $6 \times 6$ complete diallel cross in durum wheat

\begin{tabular}{|c|c|c|c|c|c|c|}
\hline زَنوتيب & $\begin{array}{l}\text { No. of fertile } \\
\text { tiller }\end{array}$ & $\begin{array}{l}\text { طول سنبله } \\
\text { (سانتى متر) } \\
\text { Spike length } \\
\text { (cm) }\end{array}$ & $\begin{array}{l}\text { تعداد دانه در سنبله } \\
\text { No. of grain per } \\
\text { spike }\end{array}$ & $\begin{array}{c}\text { وزن هزار دانه (كرم) } \\
\text { Hundred grain } \\
\text { weight } \\
\text { (g) }\end{array}$ & $\begin{array}{l}\text { طول يدانكل } \\
\text { Peduncle length } \\
\text { (سانتى (cm) }\end{array}$ & $\begin{array}{c}\text { عملكرد دانه } \\
\text { (گرم در بوته) } \\
\text { Grain yield } \\
\text { (g/plant) }\end{array}$ \\
\hline 1 & 4.00 & 6.96 & 19.90 & 5.11 & 19.51 & 4.82 \\
\hline $1 * 2$ & 5.00 & 6.55 & 13.40 & 3.18 & 27.17 & 1.75 \\
\hline $1 * 3$ & 4.50 & 7.32 & 23.05 & 5.66 & 36.58 & 7.35 \\
\hline $1 * 4$ & 4.50 & 6.21 & 17.85 & 4.75 & 35.92 & 3.82 \\
\hline $1 * 5$ & 4.00 & 7.72 & 28.60 & 6.47 & 29.33 & 7.95 \\
\hline $1 * 6$ & 4.00 & 7.23 & 19.91 & 5.07 & 25.50 & 4.05 \\
\hline $2 * 1$ & 5.00 & 9.77 & 22.00 & 5.67 & 35.83 & 6.22 \\
\hline 2 & 4.00 & 7.75 & 30.15 & 6.80 & 35.33 & 10.33 \\
\hline $2 * 3$ & 4.50 & 7.33 & 24.90 & 5.75 & 23.00 & 9.56 \\
\hline $2 * 4$ & 3.50 & 6.72 & 26.95 & 6.91 & 24.08 & 6.53 \\
\hline $2 * 5$ & 3.50 & 6.71 & 36.50 & 5.33 & 32.85 & 7.59 \\
\hline $2 * 6$ & 4.50 & 5.47 & 14.20 & 3.23 & 32.33 & 1.25 \\
\hline $3 * 1$ & 3.00 & 6.97 & 31.24 & 6.56 & 28.08 & 9.21 \\
\hline $3 * 2$ & 3.50 & 7.34 & 25.00 & 7.08 & 34.75 & 6.02 \\
\hline 3 & 4.50 & 4.20 & 10.81 & 2.18 & 24.42 & 0.98 \\
\hline $3 * 4$ & 3.50 & 4.87 & 14.00 & 3.72 & 22.50 & 1.80 \\
\hline $3 * 5$ & 3.50 & 7.29 & 24.90 & 6.70 & 36.50 & 6.83 \\
\hline $3 * 6$ & 3.00 & 5.68 & 19.00 & 4.48 & 31.63 & 2.55 \\
\hline $4^{*} 1$ & 4.00 & 6.68 & 18.10 & 4.89 & 25.50 & 3.61 \\
\hline $4 * 2$ & 3.50 & 4.92 & 14.27 & 3.01 & 23.42 & 1.51 \\
\hline $4 * 3$ & 2.50 & 5.58 & 24.10 & 5.45 & 24.67 & 4.97 \\
\hline 4 & 3.50 & 4.06 & 16.87 & 3.44 & 24.33 & 2.13 \\
\hline $4 * 5$ & 2.50 & 3.82 & 20.93 & 3.28 & 23.32 & 1.72 \\
\hline $4 * 6$ & 3.00 & 4.62 & 19.90 & 3.97 & 23.33 & 2.22 \\
\hline $5^{*} 1$ & 2.50 & 7.93 & 18.71 & 5.32 & 30.51 & 2.29 \\
\hline $5 * 2$ & 3.50 & 6.22 & 18.43 & 4.79 & 27.00 & 2.99 \\
\hline $5 * 3$ & 2.50 & 7.33 & 28.75 & 8.09 & 29.21 & 5.73 \\
\hline $5^{*} 4$ & 2.50 & 5.60 & 20.00 & 5.14 & 25.83 & 2.53 \\
\hline 5 & 2.50 & 5.59 & 18.30 & 3.82 & 28.17 & 1.68 \\
\hline $5^{*} 6$ & 4.00 & 8.16 & 26.70 & 7.63 & 31.25 & 12.13 \\
\hline $6^{*} 1$ & 3.50 & 6.66 & 21.63 & 4.39 & 30.17 & 3.25 \\
\hline $6 * 2$ & 3.50 & 6.77 & 31.10 & 7.56 & 31.84 & 10.04 \\
\hline $6 * 3$ & 4.00 & 5.94 & 23.75 & 6.01 & 27.00 & 7.11 \\
\hline $6 * 4$ & 3.00 & 5.17 & 14.70 & 3.58 & 31.68 & 1.57 \\
\hline $6 * 5$ & 3.50 & 5.12 & 19.43 & 4.88 & 24.33 & 2.94 \\
\hline 6 & 5.00 & 7.12 & 24.40 & 6.65 & 29.00 & 8.90 \\
\hline Mean \pm & $3.64 \pm 0.13$ & $6.37 \pm 0.22$ & $21.73 \pm 0.97$ & $5.18 \pm 0.25$ & $28.5 \pm 0.77$ & $4.89 \pm 0.52$ \\
\hline LSD 5\% & 1.59 & 2.47 & 11.22 & 3.05 & 10.15 & 3.48 \\
\hline
\end{tabular}

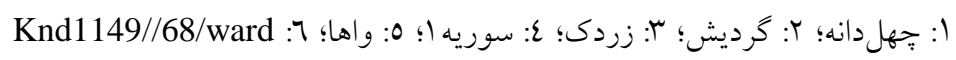

LSD 5\%: Least Significant Difference at 5\% probability level

1: Chehel daneh; 2: Gerdish; 3: Zardak; 4: Syrian-1; 5: Waha; 6: Knd1149//68/ward 
Mohammadi and ) محمدى و خدامباشى امامى نيز بس از (Khodambashi Emami, 2008 اطمينان از صادق بودن فرضيات مدل افزايشى - غالبيت اقدام به تجزيه دادهها با استفاده از روش كر افيكى نمودند. با توجه به نتايج آزمون فوق مىتوان جنين نتيجه كرفت

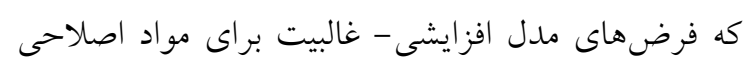

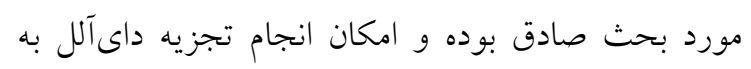
روش كرافيكى هيمن وجود داشت.

نتايج حاصل از تجزيه واريانس دىآلل بر اساس روش هيمن (Hayman, 1954) در جدول 0 ارائه گرديده است. براى صفاتى كه مدل افزايشى - غالبيت كفايت نمىنمود، تجزيه واريانس يس از حذف والد يا والدين مورد نظر انجام شد و لذا در جدول تجزيه واريانس فوق، درجه آزادى براى صفات مورد مطالعه متفاوت ارائه شده است. ميانخين مربعات اثر افزايشى (a) براى تمام صفات مورد مطالعه معنى دار بود. همجنين ميانخين مربعات اثر غالبيت

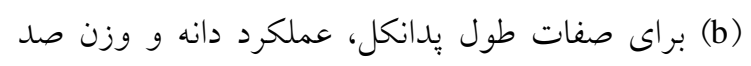
دانه معنى يك جهتى و وجود تفاوت بين ميانخين والدين و نتاج است. همجنين معنى دار بودن br، نشاندهنده بزرگتر

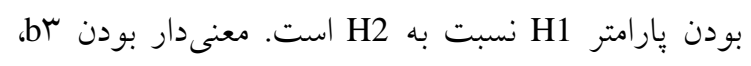

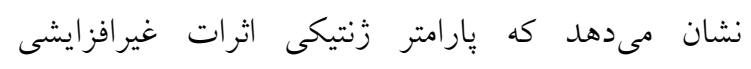

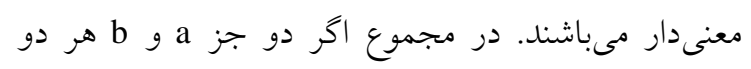
معنىدار باشند، واريانس افزايشى و غالبيت در كتترل

صفت سهيم هستند (Roy, 2000).
آزمون مقدماتى به روش جينكز و هيمن ( Jinks and Wr نشان داد كه شيب خط رگرسيون (Hayman, 1953 (كوواريانس نتاج هر رديف با والدهاى غيرمشترك) روى (واريانس نتاج هر رديف) براى صفات طول بدانكل و لr طول سنبله واجد اختلاف معنىدار با صفر و فاقد اختلاف معنىدار با ا بود، بنابراين براى اين صفات فرضيات مدل كفايت مىنمود (جدول ع). براى ساير صفات ضريب

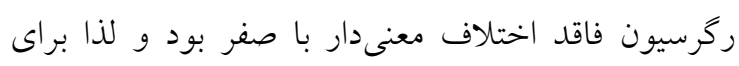
صفات عملكرد دانه، تعداد دانه در سنبله و وزن صد دانه والد اول (جهلدانه) و براى صفت تعداد ينجه بارور

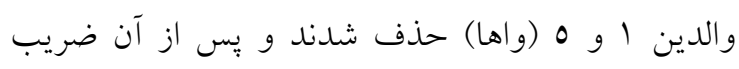
رگرسيون واجد اختلاف معنىدار با صفر و فاقد اختلاف معنىدار با ا شد؛ بنابراين مىتوان اظهار نمود كه زنوتيبٍ جهادانه حاوى زنهاى داراى اثرات إيبستاتيك براى صفات فوق بوده است كه با حذف آن فرضيات تجزيه

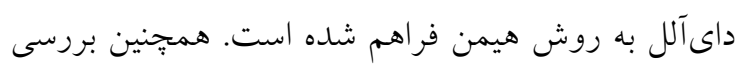
آماره Wr-Vr يس از حذف والدين فوق، مطابق با نتايج

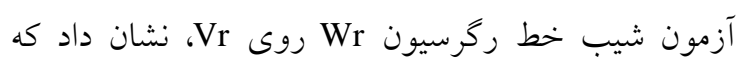

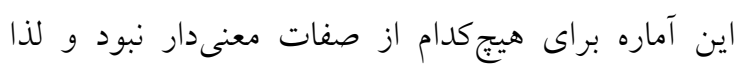
نشانخر عدم وجود اثرات اييستاتيك در كنترل صفات فوق إن برت

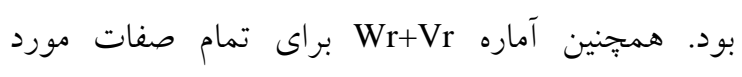
مطالعه معنىدار بود. لذا بيشفرضهاى لازم براى تجزيه

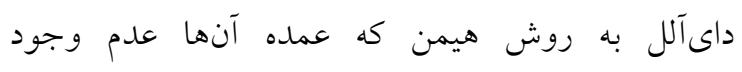
اييستازى يا اثرات متقابل زنهاى غير آللى كنترل كننده صفات در والدين مورد تلاقى است، صادق مىباشد. در تطابق با نتيجه تحقيق حاضر، صادقى (Sadeghi, 2014) و

جدول ع- آزمون ضرايب رگرسيون Wr روى Vr براى صفات مورد مطالعه در گندم دوروم

Table 4. Test of regression coefficients of $\mathrm{Wr} / \mathrm{Vr}$ for studied traits in durum wheat

\begin{tabular}{|c|c|c|c|c|c|c|}
\hline صفت & Character & $\mathrm{b} \pm \mathrm{sb}$ & $\begin{array}{c}\mathrm{H}_{0}: \beta=0, \\
\text { t value }\end{array}$ & $\begin{array}{c}\mathrm{H}_{0}: \beta=1, \mathrm{t} \\
\text { value }\end{array}$ & $\begin{array}{l}\mathrm{Wr}+\mathrm{Vr}, \\
\text { t value }\end{array}$ & $\begin{array}{l}\text { Wr-Vr, } \\
\text { t value }\end{array}$ \\
\hline طول يِ إنكل (سانتى متر) & Peduncle length $(\mathrm{cm})$ & $1.01 \pm 0.34$ & $2.99^{*}$ & $-0.04^{\mathrm{ns}}$ & $3.71^{*}$ & $1.54 \mathrm{~ns}$ \\
\hline عملكرد دانه (كرم در بوته) & Grain yield (g/plant) & $0.87 \pm 0.19$ & $4.65^{* *}$ & $0.68^{\text {ns }}$ & $4.19^{* *}$ & $-1.13^{\mathrm{ns}}$ \\
\hline تعداد دانه در سنبله & No. of grain per spike & $0.81 \pm 0.14$ & $5.74^{* *}$ & $1.35^{\mathrm{ns}}$ & $3.56^{*}$ & $-1.14^{\mathrm{ns}}$ \\
\hline طول سنبله (سانتىمتر) & Spike length $(\mathrm{cm})$ & $0.58 \pm 0.23$ & $2.53 *$ & $1.80^{\mathrm{ns}}$ & $3.90^{*}$ & $-1.87^{\mathrm{ns}}$ \\
\hline تعلداد ينججه بارور & No. of fertile tiller & $0.74 \pm 0.22$ & $3.33^{*}$ & $1.16^{\mathrm{ns}}$ & $3.62^{* *}$ & $-0.55^{\mathrm{ns}}$ \\
\hline وزن صد دانه (كرم) & Hundred grain weight (g) & $0.77 \pm 0.13$ & $6.10^{* *}$ & $4.54^{\mathrm{ns}}$ & $3.91^{*}$ & $0.81^{\mathrm{ns}}$ \\
\hline
\end{tabular}

ns, ${ }^{*}$ and ${ }^{* *}$ :Not significant, significant at $5 \%$ and $1 \%$ probability levels, respectively. 


$$
\text { جدول 0- تجزيه واريانس داى آلل به روش هيمن براى صفات مورفولوزيك كندم دوروم }
$$

Table 5. Analysis of variance of diallel with Hayman method for morphological traits in durum wheat

\begin{tabular}{|c|c|c|c|c|c|c|c|c|c|}
\hline $\begin{array}{l}\text { منابع تغييرات } \\
\text { SOV }\end{array}$ & درجه & $\begin{array}{c}\text { طول يدانكل } \\
\text { (سانتى متر) } \\
\text { Peduncle } \\
\text { length (cm) }\end{array}$ & $\begin{array}{c}\text { طول سنبله } \\
\text { (سانتى متر) } \\
\text { Spike length } \\
\text { (cm) }\end{array}$ & درجه & $\begin{array}{c}\text { عملكرد دانه } \\
\text { (كرم در بوته) } \\
\text { Grain yield } \\
\text { (g/plant) }\end{array}$ & $\begin{array}{c}\text { تعداد دانه در } \\
\text { No. of grain } \\
\text { per spike }\end{array}$ & $\begin{array}{l}\quad \text { وزن صد دانه } \\
\qquad \begin{array}{c}\text { Hondred grain } \\
\text { Height (g) }\end{array} \\
\text { weind }\end{array}$ & درجه آزادى & $\begin{array}{c}\text { تعداد ينجه } \\
\text { يارور } \\
\text { No. of } \\
\text { fertile tiller } \\
\end{array}$ \\
\hline $\begin{array}{c}\text { تكرار } \\
\text { Replication }\end{array}$ & 1 & $64.98^{\mathrm{ns}}$ & $2.93^{\mathrm{ns}}$ & 1 & $0.95^{\mathrm{ns}}$ & $5.33^{\mathrm{ns}}$ & $0.11^{\mathrm{ns}}$ & 1 & $0.28^{\mathrm{ns}}$ \\
\hline $\begin{array}{c}\text { اثر افزايشى (a) } \\
\text { Additive effect (a) }\end{array}$ & 5 & $52.93^{*}$ & $12.44^{* *}$ & 4 & $42.87^{* *}$ & $115.32^{* * *}$ & $6.67^{*}$ & 3 & $2.02^{*}$ \\
\hline 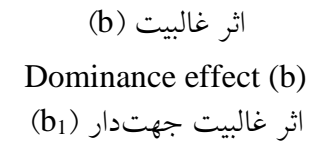 & 15 & $38.48^{*}$ & $1.75^{\mathrm{ns}}$ & 10 & $13.20^{* *}$ & $40.78^{\mathrm{ns}}$ & $5.56^{*}$ & 6 & $0.73^{\mathrm{ns}}$ \\
\hline $\begin{array}{l}\text { Directional dominance } \\
\text { effect }\left(b_{1}\right)\end{array}$ & 1 & $42.99^{\mathrm{ns}}$ & $2.52^{\mathrm{ns}}$ & 1 & $0.021^{\mathrm{ns}}$ & $40.36^{\mathrm{ns}}$ & 4.66 & 1 & $1.76^{\mathrm{ns}}$ \\
\hline 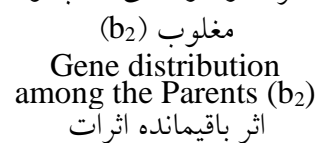 & 5 & $60.38^{* *}$ & $3.09^{*}$ & 4 & $25.10^{* * *}$ & $89.843^{*}$ & $9.76^{*}$ & 3 & $0.85^{\mathrm{ns}}$ \\
\hline $\begin{array}{c}\left(b_{3}\right) \text { غير افز" ايشى } \\
\text { Effects of specific } \\
\text { genes }\left(b_{3}\right)\end{array}$ & 9 & $25.82^{\mathrm{ns}}$ & $0.91^{\mathrm{ns}}$ & 5 & $6.83^{*}$ & $1.61^{\mathrm{ns}}$ & $2.37^{\mathrm{ns}}$ & 2 & $0.04^{\mathrm{ns}}$ \\
\hline $\begin{array}{c}\text { اثر متقابل عمومى (c) } \\
\text { General interaction } \\
\text { effect (c) }\end{array}$ & 5 & $20.19^{\mathrm{ns}}$ & $1.99^{\mathrm{ns}}$ & 4 & $7.84^{*}$ & $34.51^{\mathrm{ns}}$ & $3.26^{\mathrm{ns}}$ & 3 & $0.88^{\mathrm{ns}}$ \\
\hline $\begin{array}{c}\text { اثر متقابل خصوصى (d) } \\
\text { Reciprocal effect (d) }\end{array}$ & 10 & $55.30^{*}$ & $2.00^{\mathrm{ns}}$ & 6 & $35.55^{* *}$ & $145.42^{* * *}$ & $7.33^{* *}$ & 3 & $0.63^{\mathrm{ns}}$ \\
\hline $\begin{array}{l}\text { خط } \\
\text { Error }\end{array}$ & 35 & 19.3 & 1.47 & 24 & 3.12 & 27.1 & 1.94 & 15 & 0.48 \\
\hline
\end{tabular}

ns, * and ${ }^{* *}$ :Not significant, significant at $5 \%$ and $1 \%$ probability levels, respectively.

زن ها در كنترل زنتيكى عملكرد دانه مطابق و با نتايج ساير

Heidari et al., 2006; Singh et al., 2004; ) محققـين Sadeghi, 2014; Mohammadi and Khodambashi كه عنوان نمودهاند عمل غالبيت زنها در (Emami, 2008 كنترل اين صفت نقش مهم ترى دارد در تضاد است. دليـل اين امر مى تواند ناشى از وجود تفــاوت در والـدين مـورد مطالعه باشد. بهطور كلى با در نظر كرفتن نتايج فوق و بـا توجه به نقش بيشتر اثر افزايشى زنهـا در كنتـرل زنتيكى صفات مورد مطالعه، امكان انجـام بــروزهه هــاى مبتنى بـر كزينش در بـين نتساج وجـود دارد. ميـانخين مربعـات اثـر غالبيت جهت دار (b) براى هيج كدام از صـفات معنسى دار نبـود كـهـ حــاكى از عــدم وجــود غالبيـت جهــت دار در مكانهاى زنى كنترل كنـــه ايسن صـفات در زنوتيـٍِهـاى مورد مطالعه بود، به اين مفهوم كه در نتيجه وجود غالبيت

$$
\text { بنابراين با توجه به توضيحات فوق، براى سه صفت اخيـر }
$$

Heidari et al., 2006; Nazeer et al., 2011; Abdul ) كــ (Rehman Rashid et al., 2012; Sadeghi, 2014; كزارش كردند عملكرد و اجـزاى عملكـــد دانـهـ در گنـدم توسط اثر افزايشى و غيرافزايشى زنهــا كتــرل مسى شـود، مطابقت دارد. براى صفات عملكـرد دانـه، تعـداد دانـه در سنبله، طول سـنبله و تعـداد ينجــه بـارور سـهم واريـانس افزايشى نسبت به واريانس غالبيت بيشتر بود. ايسن نتيجـهـ

Khan et al., 2000; ) بـا تحقيقـات برخسى از محققـين Mahmood and Chowdhry, 2002; Malik et al., 2005; مبنى بــ نقـش عمـل افزايشى (Al - Hamdany, 2010; 
معنى دار بودن انواعى از غالبيت براى هر كدام از صـفات،

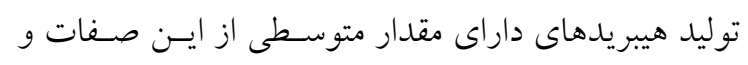

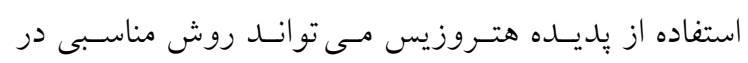
بهبود صفات مورد بررسى باشد. براى صفت عملكرد دانه

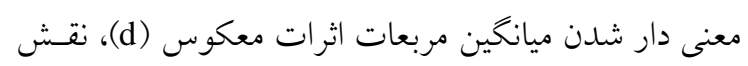

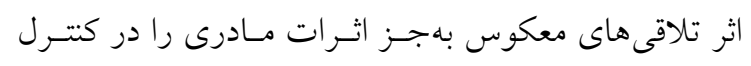

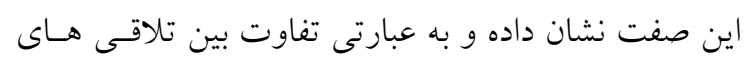
معكوس را در كتترل اين صفت بيان مى دارد. جهون تعـداد

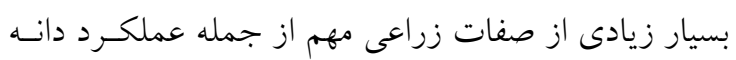

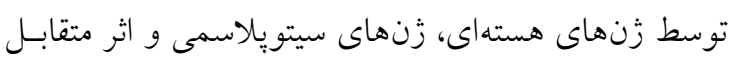

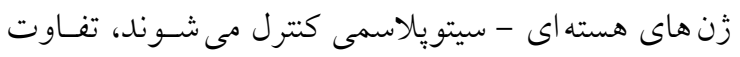

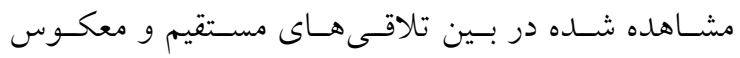

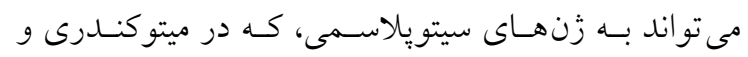

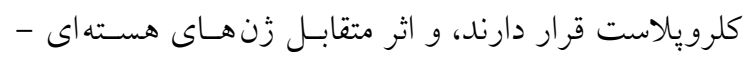
سيتو يلاسمى نسبت داده شود (Shi et al., 1997).

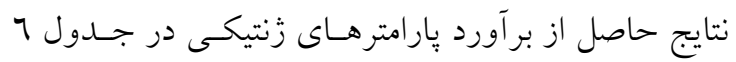

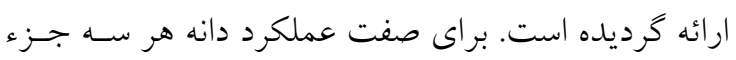

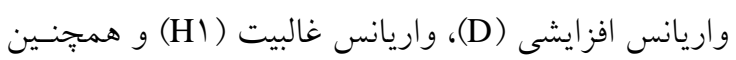

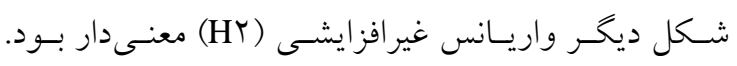

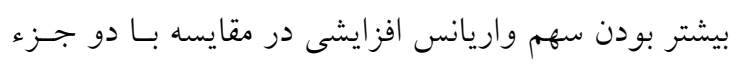

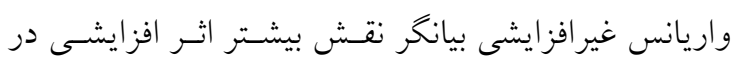

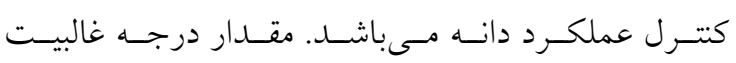
بالاتر از يك براى صفت طول بدانكل دلالت (H)/D)•/0

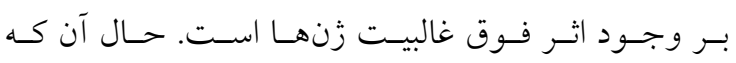

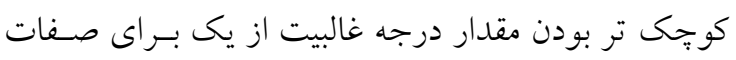

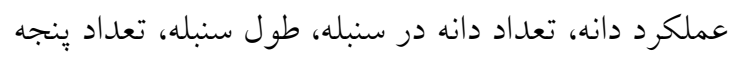

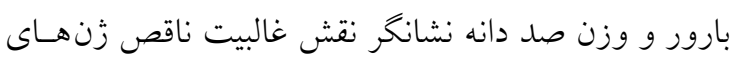
عامل اين صفات است. مقدار مثبت بـارامتر F و همجنـين

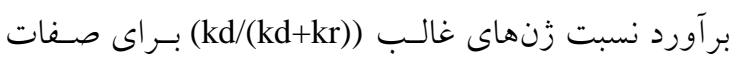

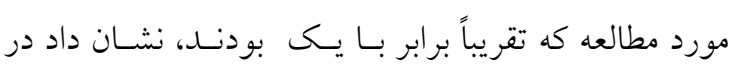

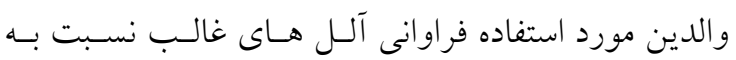
آللهاى مغلـوب بيشتر اسـت (Leng and Hong, 2004).

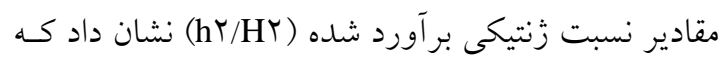
در كنترل زنتيكى صفات طول سنبله و تــعلداد يُنجه بارور
در مكان هاى زنى كنترل كننده اين صـفات بسين والــين و

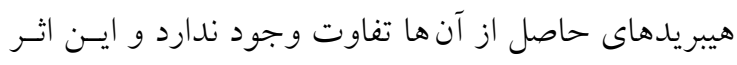

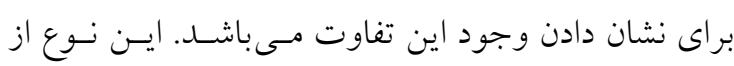

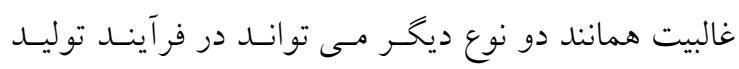

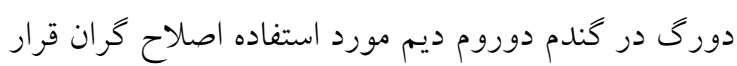

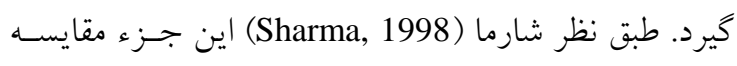

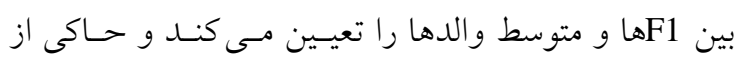

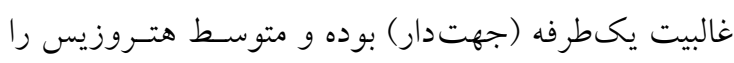

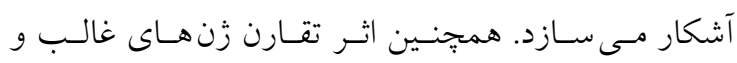

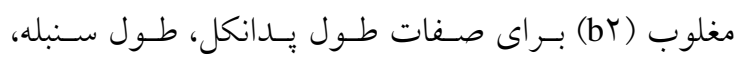
عملكرد دانه، تعداد دانه در سنبله و وزن صد دانه معنى دار بود. يعنى زن هاى كنترل كننده اين صفات در ارقـام مـورد دانه

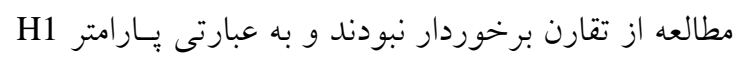
بزرگتــ از H2 اسـت (Roy, 2000) و در نتيجـه والـدين

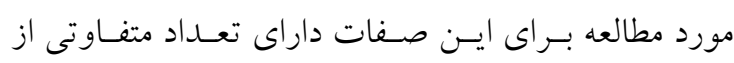

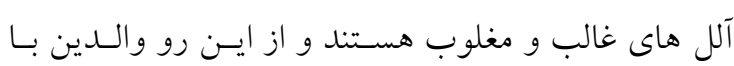

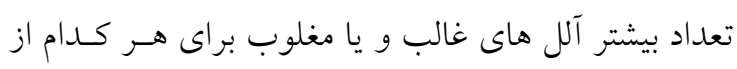

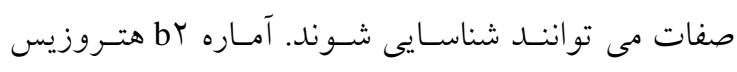

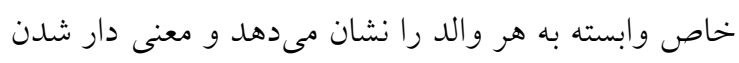

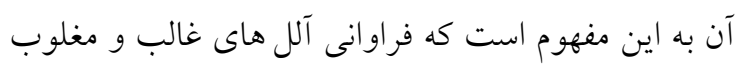

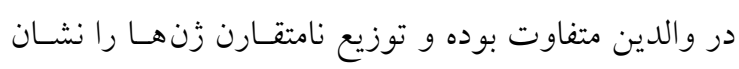

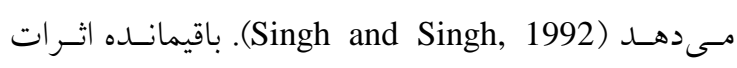

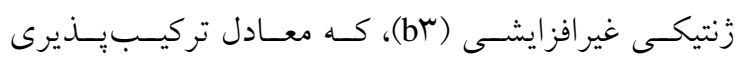

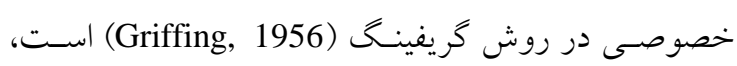

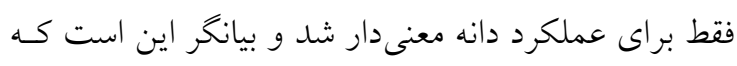

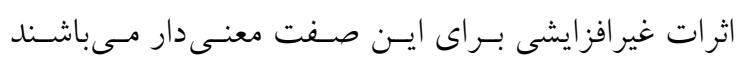

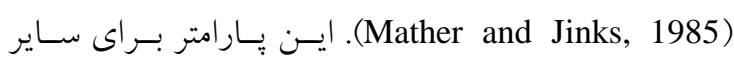

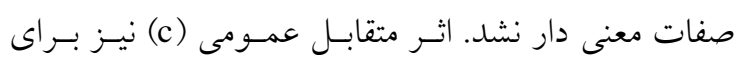

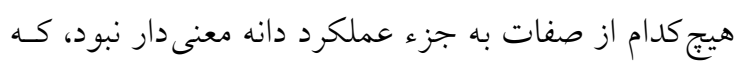
نشان مى دهد در كنترل زنتيكى اين صفت اثر مادرى نقش

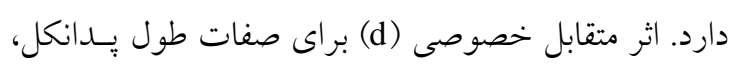

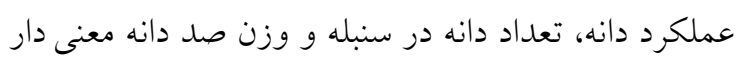
بود، كه نقش اثر تلاقى هاى معكوس بهجز اثرات مادرى را

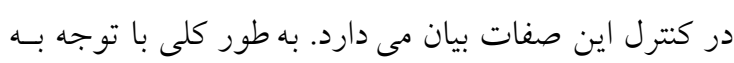




$$
\text { جدول } 7 \text { - بر آورد يار امترهاى زنتيكى براى صفات مورفولوزيك كندم دوروم }
$$

Table 6. Estimation of genetic parameters for morphological traits in durum wheat

\begin{tabular}{|c|c|c|c|c|c|c|}
\hline $\begin{array}{c}\text { بارامترهاى } \\
\text { زنتيكى } \\
\text { Genetic parameters }\end{array}$ & $\begin{array}{l}\text { طول يدانكل } \\
\text { (سانتىمتر) } \\
\text { Peduncle } \\
\text { length (cm) }\end{array}$ & $\begin{array}{c}\text { عملكرد دانه (كرم } 2 \\
\text { در بوته) } \\
\text { Grain yield } \\
\text { (g/plant) }\end{array}$ & $\begin{array}{l}\text { تعداد دانه سنبله } \\
\text { Number of grain } \\
\text { per spike }\end{array}$ & $\begin{array}{l}\text { طول سنبله } \\
\text { (سانتى متر) } \\
\text { Spike length } \\
\text { (cm) }\end{array}$ & $\begin{array}{l}\text { بارور بنجاد } \\
\text { Number of } \\
\text { fertile tiller }\end{array}$ & $\begin{array}{c}\text { وزن صد دانه) } \\
\text { وزرم) } \\
\text { Hundred } \\
\text { grain weight (g) }\end{array}$ \\
\hline $\begin{array}{c}\text { واريانس افزايشى (D) } \\
\text { Additive variance (D) }\end{array}$ & $16.29 \pm 18.76$ & $17.91 \pm 5.97$ & $41.34 \pm 28.31$ & $1.75 \pm 1.28$ & $0.49 \pm 0.53$ & $3.42 \pm 2.28$ \\
\hline $\begin{array}{c}\text { واريانس غالبيت (H1) } \\
\text { Dominance variance (H1) }\end{array}$ & $25.14 \pm 28.97$ & $16.10 \pm 7.13$ & $32.49 \pm 40.28$ & $0.82 \pm 1.69$ & $0.35 \pm 0.76$ & $5.96 \pm 3.51$ \\
\hline شكل ديخر واريانس غير افزايش (H2) & $14.08 \pm 18.47$ & $9.78 \pm 4.57$ & $14.78 \pm 25.56$ & $0.32 \pm 1.06$ & $0.28 \pm 0.58$ & $3.69 \pm 2.3$ \\
\hline $\begin{array}{l}\text { ميانخين كوواريانس اثرات افزايشى و } \\
\text { (F) غالبيت } \\
\text { Relative frequency of dominant } \\
\text { and recessive alleles (F) }\end{array}$ & $23.41 \pm 28.42$ & $16.51 \pm 7.56$ & $42.53 \pm 37.66$ & $0.45 \pm 1.62$ & $0.19 \pm 0.56$ & $4.82 \pm 3.19$ \\
\hline $\begin{array}{c}\text { (H1/D) } 0.5 \text { درجه غالبيت } 0.5 \\
\text { Average degree of dominance } \\
\left(\mathrm{H}_{1} / \mathrm{D}\right) 0.5\end{array}$ & $2.14 \pm 1.09$ & $0.94 \pm 0.18$ & $0.87 \pm 0.41$ & $0.68 \pm 0.51$ & $0.84 \pm 0.93$ & $0.91 \pm 0.38$ \\
\hline $\begin{array}{c}\text { نسبت زنهاى غالب (kd/(kd+kr)) } \\
\text { Proportion of dominance genes } \\
(\mathrm{kd} /(\mathrm{kd}+\mathrm{kr}))\end{array}$ & $0.78 \pm 0.13$ & $0.74 \pm 0.04$ & $0.79 \pm 0.18$ & $0.59 \pm 0.19$ & $0.61 \pm 0.47$ & $0.76 \pm 0.06$ \\
\hline $\begin{array}{c}\left(\mathrm{h}^{2} / \mathrm{H}_{2}\right) \text { تعداد فاكتورهاى مؤثر } \\
\text { Number of effective factors } \\
\left(\mathrm{h} 2 / \mathrm{H}_{2}\right)\end{array}$ & $0.47 \pm 2.69$ & $0.13 \pm 0.16$ & $0.43 \pm 29.76$ & $1.23 \pm 4.79$ & $2.36 \pm 5.59$ & $0.32 \pm 0.48$ \\
\hline $\begin{array}{c}\text { (h) متوسط جهت غالبيت } \\
\text { Average direction of dominance } \\
\text { (h) }\end{array}$ & $3.45 \pm 2.71$ & $0.08 \pm 1.06$ & $3.59 \pm 3.06$ & $0.83 \pm 0.64$ & $-0.81 \pm 0.25$ & $1.22 \pm 0.76$ \\
\hline $\begin{array}{l}\text { وراثتيذيرى مربوط به والدين } \\
\text { واين } \\
\text { Heritability by parents (D/(D+E)) }\end{array}$ & $0.56 \pm 0.28$ & $0.91 \pm 0.04$ & $0.75 \pm 0.15$ & $0.70 \pm 0.17$ & $0.67 \pm 0.41$ & $0.78 \pm 0.19$ \\
\hline $\begin{array}{c}\left(h^{2} b\right) \text { وراثت يذيرى عمومى (h2b) } \\
\text { Broad-sense heritability }\end{array}$ & $0.30 \pm 0.14$ & $0.78 \pm 0.07$ & $0.47 \pm 0.14$ & $0.56 \pm 0.10$ & $0.51 \pm 0.18$ & $0.58 \pm 0.12$ \\
\hline $\begin{array}{c}\left(h^{2} n\right) \text { وراثت يذيرى خصوصى heritability h2n } \\
\text { Narrow-sense he }\end{array}$ & $0.11 \pm 0.11$ & $0.48 \pm 0.09$ & $0.32 \pm 0.14$ & $0.52 \pm 0.09$ & $0.36 \pm 0.17$ & $0.18 \pm 0.11$ \\
\hline $\begin{array}{l}\text { نسبت زنهاى داراى اثرات غالبيت و } 2 \text { مغلوبيت } \\
\left(\mathrm{H}_{2} / 4 \mathrm{H}_{1}\right) \\
\text { Proportion of dominance and } \\
\text { recessive genes }\left(\mathrm{H}_{2} / 4 \mathrm{H}_{1}\right)\end{array}$ & 0.14 & 0.15 & 0.11 & 0.10 & 0.20 & 0.15 \\
\hline
\end{tabular}

زنى كنترل كننده براى يك صفت مىباشـد (Roy, 2000). از آنجا كه اين نسبت براى تمام صفات مورد مطالعه كمتر

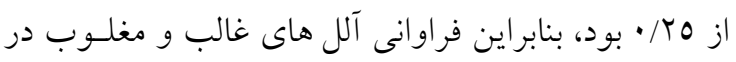
مكانهاى زنى كنترل كننده اين صفات مساوى نبود. ميـزان

$$
\begin{aligned}
& \text { حداقل دو گروه زنى دخالت داشتند. در حالى كه در ساير }
\end{aligned}
$$

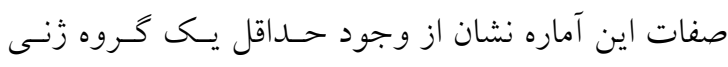

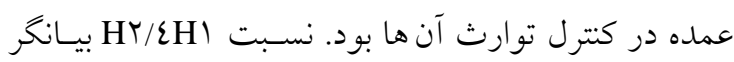

$$
\begin{aligned}
& \text { تقارن فراوانى آلل هاى غالب و مغلوب در تمام مكانهـاى }
\end{aligned}
$$


صفات تعداد يُنجه بارور، تعداد دانه در سـنبله و عملكـــد

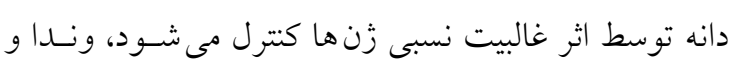
هوشمند (Vanda and Houshmand, 2011) نشـان دادنــ كه صفات فوق تحت كنــرل اثـرات فـوق غالبيـت زن هـا Heidari et al., ) بودنـد. از طرفى حيـدرى و همكـاران 2006) نشان دادند كه نوع عمل زن در مورد تعداد دانه در سنبله از نوع غالبيت ناقص، ولى در ارتباط با عملكرد دانه تـك بوتـهـ و وزن هــزار دانـهـ از نـوع فـوق غالبيـت بــود. همجنين محمدى و خدامباشى امامى ( Mohammadi and (Khodambashi Emami, 2008

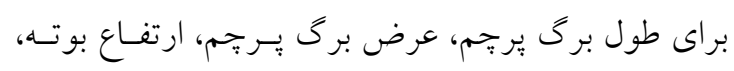

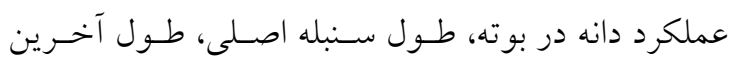
ميانخره و وزن آخرين ميانخره از نوع غالبيت نسبى اسـت.

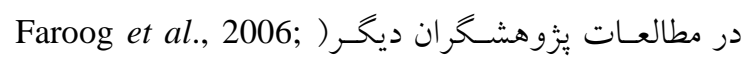
مشخص شد كه اثر فوق غالبيت در (Rahim et al., 2006 كنترل زنتيكى طول سنبله، تعداد سنبلهُه در سـنبله و وزن هزار دانه دخالت دارند. دليل تغاير نتايج تحقيق حاضر بـا نتايج تحقيقـات سـاير محققسين مسى توانـــ بـهـ تفـاوت در زنوتيڤٍاى مورد مطالعه در تحقيقات مختلف باشد. والدين در طول خط ركرسـيون بخصـوص بــراى صـفات

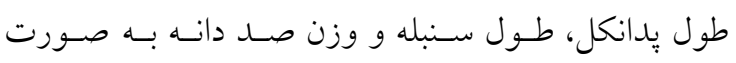
يراكنده قرار داشتند كه بيـانكر تنـوع زنتيكسى و همجنـين وجود زن هاى غالب و مغلـوب در والـدين مـورد مطالعـهـ

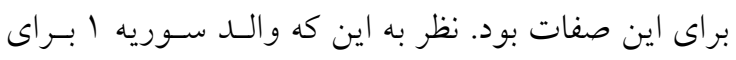
صفات طول يدانكل، عملكرد دانه، تعـداد ينجـهـ بـارور و

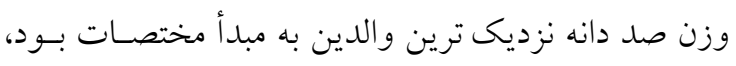
داراى بيشترين وفور آلل هاى غالب بـراى صـفات مـذكور بود. از طرف ديخر والــ جهـل دانـه، بـراى صـفت طـول بِدانكل، والد زردى بـراى صـفات وزن صـــ دانـه، طـول سنبله، تعداد دانه در سنبله و عملكرد دانه و همجِنين والــ Knd1149//68/ward براى تعداد ينجه بارور در دورتـرين

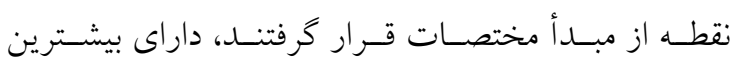
آلل هاى مغلوب بودند. نتايج حاصل از نسبت هاى غالبيـت كه در جدول V ارائه شده است، نيز مؤيد اين نكته اسـت.
وراثت يذيرى براى صفت عملكرد دانه تقريباً بـالا (VN •)،

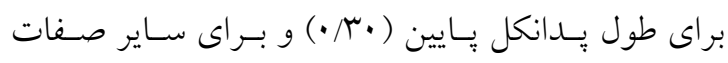

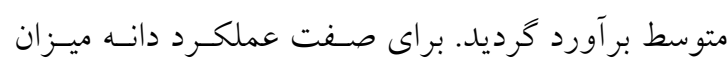

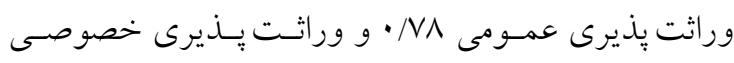

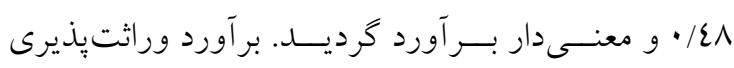
عمومى و خصوصى براى ايـنن صــفت نــشان داد كــه

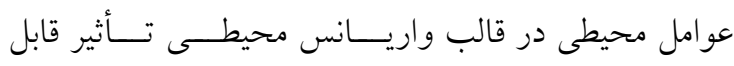
توجهى بر صفت فوق كذاشته است و بعلاوه با توجــه به

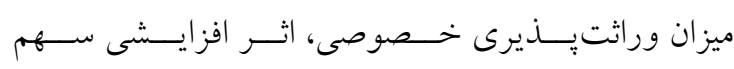

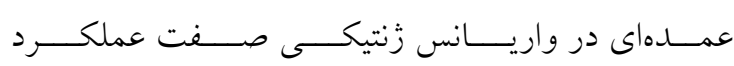

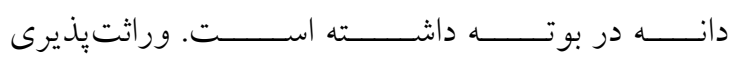
خصوصى برابر با Or/Or • مؤيد نقش اتــــر افزايــشى زن هـا

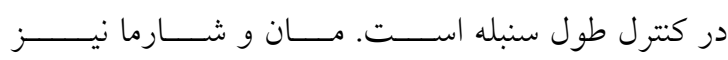
وراثـتــــــ (Mann and Sharma , 1995) تــا بــالائى را بـــراى ايــن صفت گز ارش نمودند. نـاظر

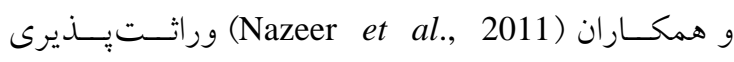
خصوصى بالايى را براى تعداد سنبلهُ در سـنبله و تعـداد Eqbal et ( دانه در سنبله گزارش نمودند. اقبال و همكار (Heidari et al., 2006) و حيدرى و همكاران (al., 2007 نيز ميـزان بـالايى از وراتـت يـــيرى عمـومى را در گذــدم كزارش نمودند. تجزيه كرافيكى Wr روى Vr براى ميانخين تمـام صـفات مطالعه شده در شكل هاى ا تـا 7 نشـان داده شــه اسـت. براى صفات عملكــرد دانـه، تعــاد دانـهـ در ســبله، طـول سنبله، تعداد ينجه بارور و وزن صد دانـه خـط رگرسـيون

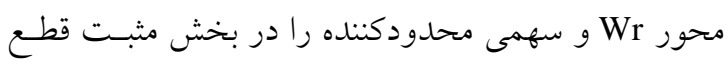

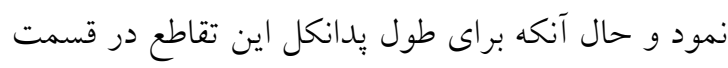

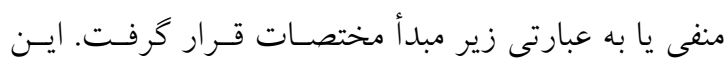
نشان مى دهد كه عمل زن براى ينج صفت اول به صـورت غالبيت نسبى ولى براى صفت طول بدانكل به شكل فـوق لِ له غالبيت بود. دليل عدم وجود بعضى از والدين در برخى از شكل ها، عدم كفايت مدل كامل و در نتيجه حذف يكى يـا جند والد و انجام تجزيه مجدد بر روى باقيمانـده والـدين مى باشد. برخلاف نتيجه تحقيق حاضر كه نشـان مسى دهـد 
جهل دانه قرار داشتند. با توجـهـ بـه اينكـهـه رقـم جهـل دانـه داراى كمترين طول بِدانكل در بين والـدين مـورد مطالعسه

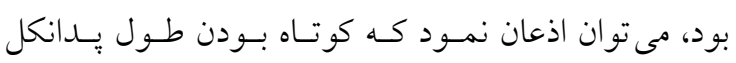
توسط آللهاى مغلوب كنترل مى شود.

شكل r مربوط به كنتـرل زنتيكى عملكــــ دانسه اسـت و نشان مى دهد كه رقم زردك با كمترين عملكرد دانه (91/• كرم در بوته) در بين والـدين مـورد مطالعسه در دورتـرين نقطه و رقم گرديش با بيشترين عملكرد دانه در ميانه خط، اما نزديك به رقم زردك، قـرار داشـت و مسى تـوان نتيجـهـ كرفت كه افزايش و كاهش عملكرد دانه تحت تـأثير تــوأم آلل هاى غالب و مغلوب اسـتـ. لانــــــ و همكـــــــاران (Lonc et al., 1993) دست يافته بودند. نسبت هاى غالبيت (جدول V) نيز نشـان مى دهند كه رقم سوريه ا داراى بيشترين آللهاى غالـب و

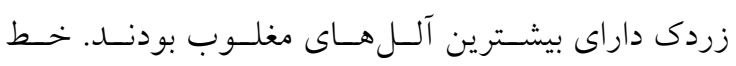
ركرسيون محور Wr را در بالاى مبدأ مختصات قطع كرده است، بنابراين عمل غالبيـت نسـبى زن هـا در كتــرل ايـن صفت مؤثر بوده است. برخى مطالعات قبلى نيز بـه عمـل غالبيت نسبى زن براى اين صفت اشاره كردهاند ( Zecevic Mohammadi and Khodambashi set al., 1997
زَنوتيتٍ هاى واقع در قسمت يايين خـط ركرسـيون داراى زن هاى غالب بودند، زيرا نتاج مربوط به والدى كـه داراى زن هاى غالب است، تقريباً يكنواخت بوده و رديف مربوط به آنها داراى حداقل واريانس مسىباشــ ( Kearsey and

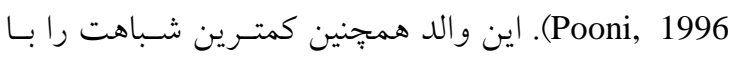
والد غيرمشترك دارد و در نتيجه نقطه مربوط به اين والـد Mather and ) در بـايين خـط ركرسـيون قـرار مسى گيــرد .(Jinks, 1985 شكل ا مربوط به صفت طول بِدانكل است و قرار گرفتن ارقام سوريه ا و جهـل دانـه در نزديـكتـــــن و دورتـرين نقطه از مبدأ مختصات بيانكر اين است كه اين دو رقم بـهـ ترتيـب حساوى بيشـترين آلـلهــاى غالــب و مغلــوبـ كنترل كننده ايـن صـفت بودنــــ ارقـام گــــيش، زردى و Knd1149//68/ward كه در وسـط مبــأ مختصـات قـرار داشـتند، داراى تركيبـى از آلـلهـــاى غالــب و مغلــوبـ مى باشند. هر جقدر نسبت غالبيت بيشتر باشد، بيـانكر ايسن است كه تعداد آلل هاى غالب در كنتـرل آن صـفت بيشـتر است. بيشترين و كمترين مقدار نسبت غالبيت براى طـول

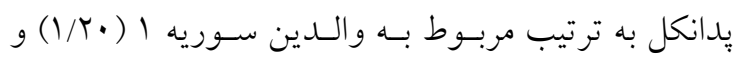

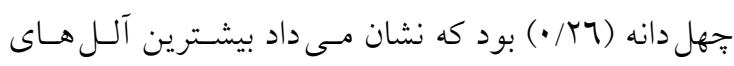

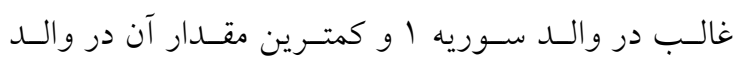

.(Emami, 2008; Weber, 1991

$$
\text { جدول V- برآورد نسبتهاى غالبيت براى صفات مورفولوزيك در كندم دوروم }
$$

Table 7. Estimation of dominance ratios for morphological traits in durum wheat

\begin{tabular}{|c|c|c|c|c|c|c|}
\hline \multirow{3}{*}{ زَنوتيِ } & طول يدانكل & عملكرد دانه & تعداد دانه & طول سنبله & تعداد ينجه & وزن صد دانه \\
\hline & (سانتى متر ) & (كرم در بوته) & در سنبله & (سانتى متر ) & بارور & (كرم) \\
\hline & $\begin{array}{c}\text { Peduncle } \\
\text { length }(\mathrm{cm})\end{array}$ & $\begin{array}{c}\text { Grain yield } \\
\text { (g/plant) }\end{array}$ & $\begin{array}{c}\text { Number of } \\
\text { grain per spike }\end{array}$ & $\begin{array}{l}\text { Spike length } \\
(\mathrm{cm})\end{array}$ & $\begin{array}{l}\text { Number of } \\
\text { fertile tiller }\end{array}$ & $\begin{array}{c}\text { Hundred grain } \\
\text { weight }(\mathrm{g})\end{array}$ \\
\hline $\begin{array}{c}\text { جهل } 2 \text { جانهel daneh } \\
\text { Chehel }\end{array}$ & 0.26 & - & - & 0.99 & - & - \\
\hline كرديش & 0.54 & 0.71 & 0.81 & 0.71 & 0.92 & 0.93 \\
\hline 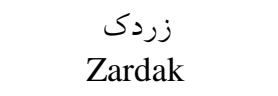 & 0.79 & 0.63 & 0.20 & 0.01 & 0.65 & 0.3 \\
\hline سوريه 1 & 1.20 & 0.99 & 1.09 & 0.69 & 1.22 & 0.98 \\
\hline $\begin{array}{l}\text { L و و } \\
\text { Waha }\end{array}$ & 1.01 & 0.69 & 0.87 & 0.52 & - & 0.84 \\
\hline Knd1149//68/ward & 0.94 & 0.69 & 0.97 & 0.69 & 0.01 & 0.79 \\
\hline
\end{tabular}




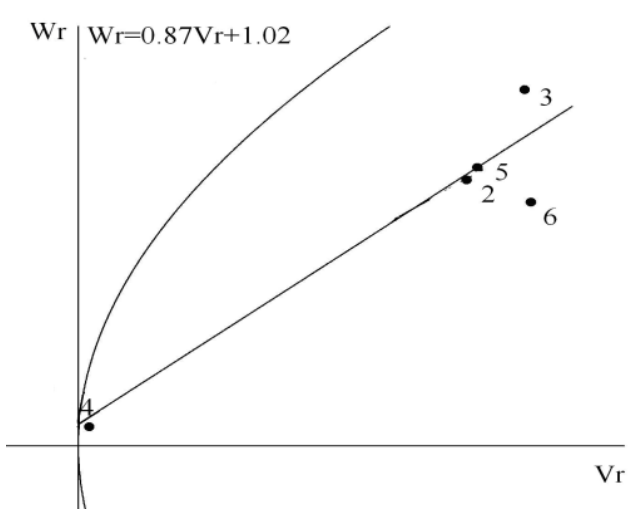

شكل r- ركرسيون Wr بر روى Vr براى عملكرد دانه در بوته (r: گرديش؛ س؟: زردك؛ ع: سوريه ا؛ 0: واها؛ $7:$

\section{(Knd1149//68/ward}

Figure 2. Regression of $\mathrm{Wr} / \mathrm{Vr}$ for grain yield per plant (1: Chehel daneh; 2: Gerdish; 3: Zardak; 4:

Syrian-1; 5: Waha; 6: Knd1149//68/ward)

وضعيت حد واسط را داشتند. از آنجا كه والدين جهل دانه، كرديش و Knd1149//68/ward داراى حداكثر طول سنبله بودند، مى توان اظهار نمود كه افزايش طول سـنبله توسط تركيبى از آلل هاى غالب و مغلوب كنترل مى شـود (شـكل

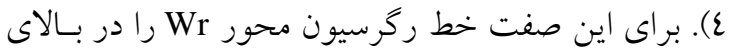

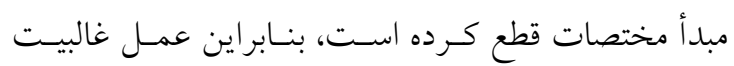

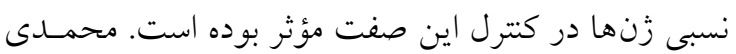

و خدامباشى امـامى ( Mohammadi and Khodambashi نيز عمل غالبيت نسبى زنها را در كتــرل (Emami, 2008 صفت طول سنبله گزارش نمودند، امـا مــــان و شــــــارما (Mann and Sharma , 1995) براى اين صفت اشاره كردهاند. در شكل ه همانطسور كـه.

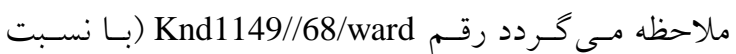
غالبيت برابر با (•/•) بـا حـــاكثر تعـداد پِنجـه بـارور در

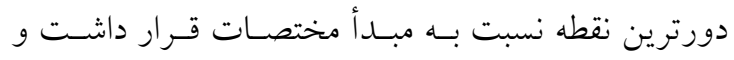

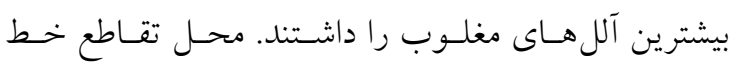

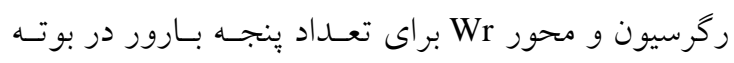

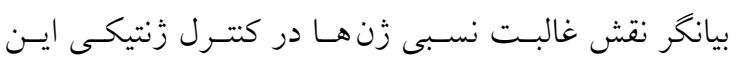

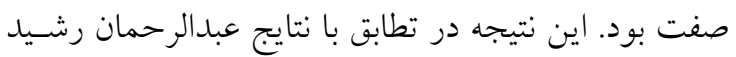
و همكـاران (Abdul Rehman Rashid et al., 2012) و خان و همكاران (Khan et al., 2000) مىباشـــ از طـرف

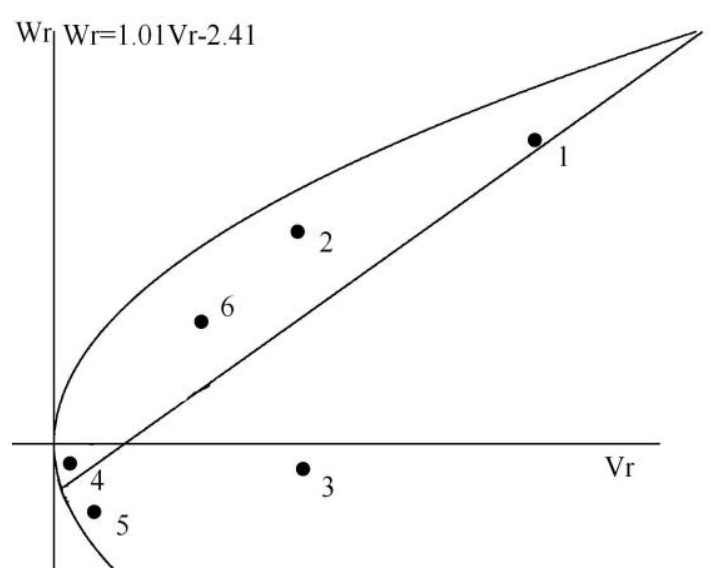

شكل 1- ركرسيون Wr بر روى Vr براى طول يدانكل (1) جهلدانه؛ ז: كرديش؛ rا: زردك؛ ع: سوريه ا؛ 0: واها؛ 7:

\section{(Knd1149//68/ward}

Figure 1. Regression of $\mathrm{Wr} / \mathrm{Vr}$ for peduncle length (1: Chehel daneh; 2: Gerdish; 3: Zardak; 4: Syrian-1; 5: Waha; 6: Knd1149//68/ward)

رقم زردى با كمترين تعداد دانه در سـنبله در دورتـرين و

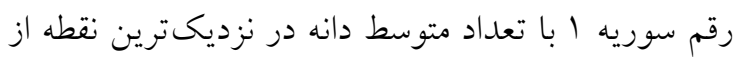

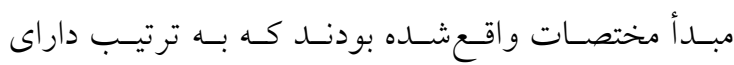
بيشترين آلل هاى غالب و مغلوب بودند. خـط ركرسيون،

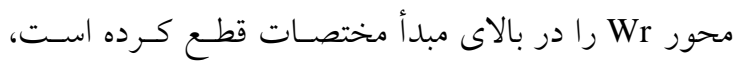

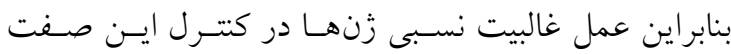
مؤثر بوده است. در تطابق با نتيجه تحقيق حاضر، حيـدرى و همكاران (Heidari et al., 2006)، عبدالرحمان رشسيد و همكاران (Abdul Rehman Rashid et al., 2012) و نـاظر و همكاران (Nazeer et al., 2011) غالبيت نسبى زنهـا را در كنترل تعداد دانه در سنبله گزارش نمودند.

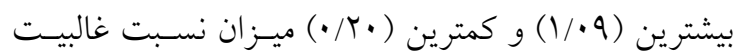
نيز به ترتيب در والدين سوريه ا و زردك قرار داشتند. از طرفى رقم كرديش با بيشترين تعداد دانه در سنبله در ميانه قرار داشت. اين نتيجه مبين كنترل زنتيكى تعداد كمتر دانه

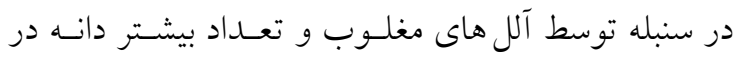

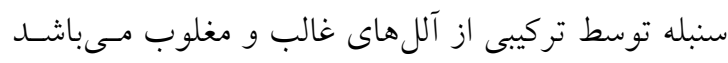

براى صفت طول سـنبله، رقـم جهـل دانـه داراى بيشـترين

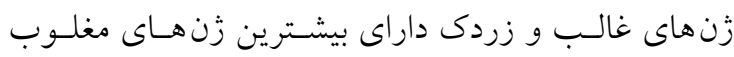

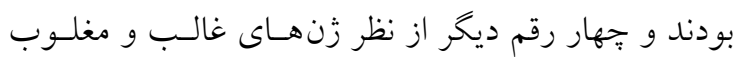




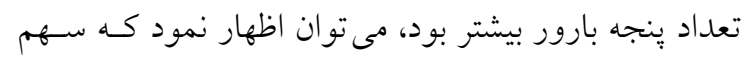

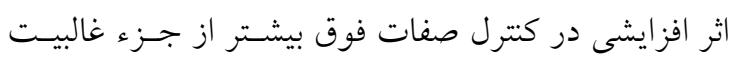

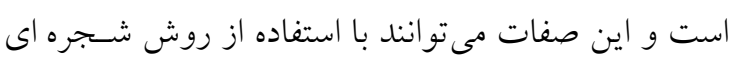

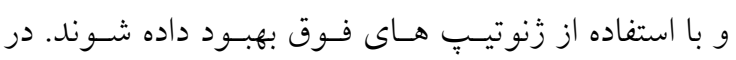

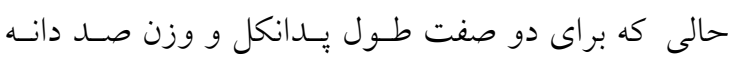

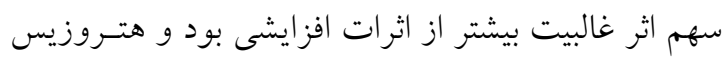

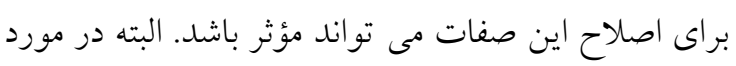

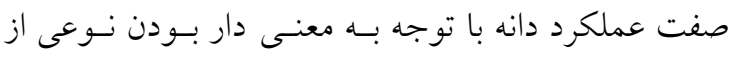

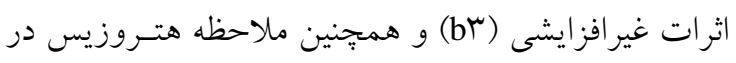

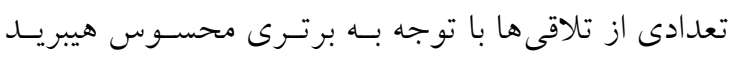

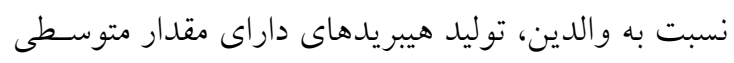

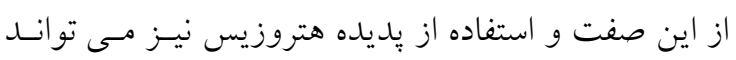

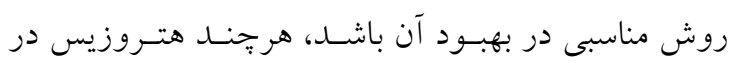

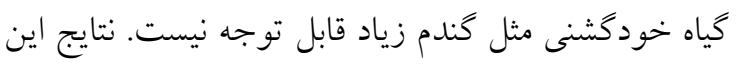

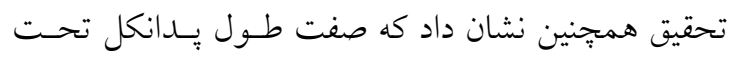
تأثير عمل فوق غالبيت زن ها قرار دارد. حال آن كه صفات

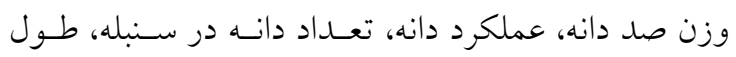

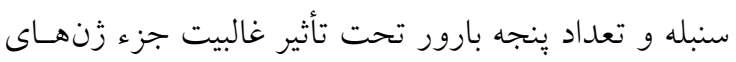

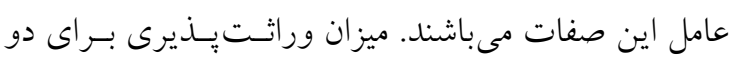

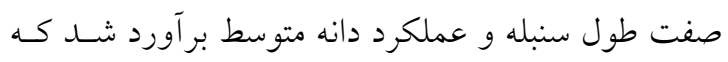

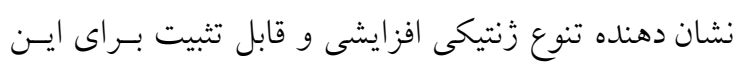

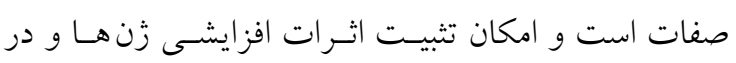
نتيجه كزينش در بين نتاج براى اين صفات در مقايسـه بـا

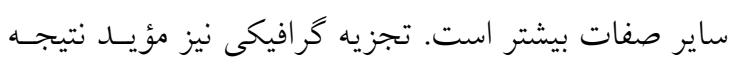

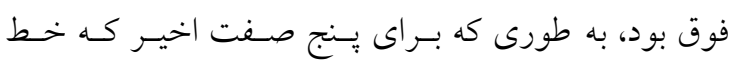

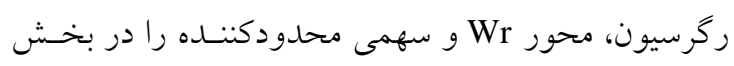

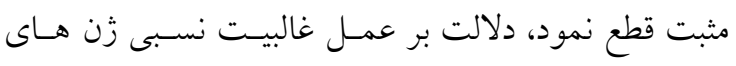
كنترل كننده داشت، ولى براى طول يدانكل ايـن تقـاطع در

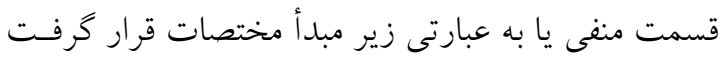

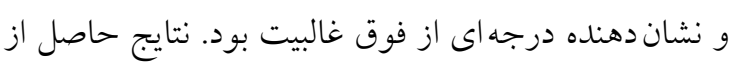

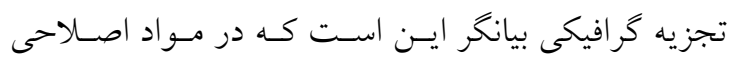

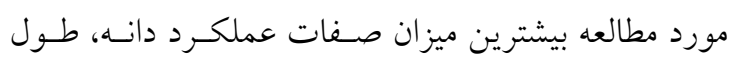
بدانكل، وزن صددانه، تعداد دانه در غلاف و طـول ســبنه

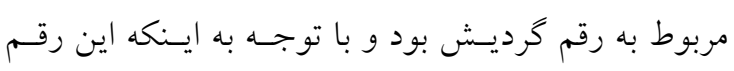

ديخر ارقام كرديش، زردى و سوريه ا با تعداد بنجهه بارور

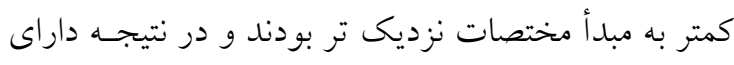

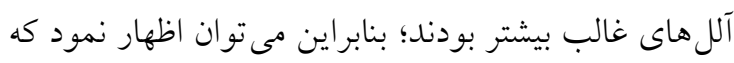

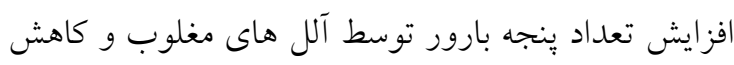
آن توسط آللهاى غالب كنترل مى شودد. ير اكندگى والدها در طول خط ركرسيون نشان داد كه رقم

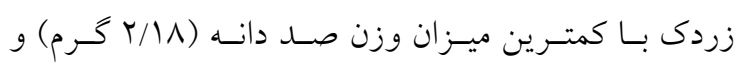

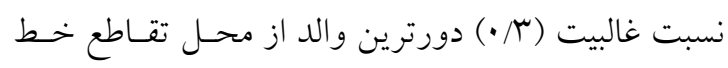

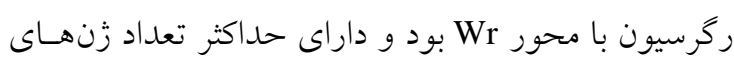

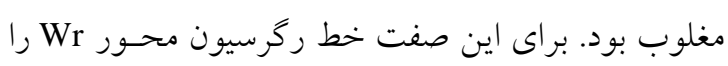

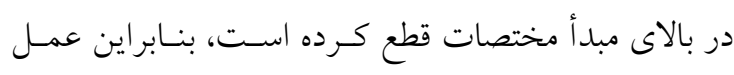

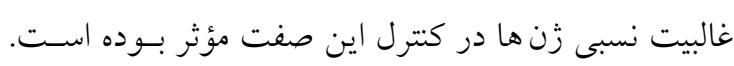

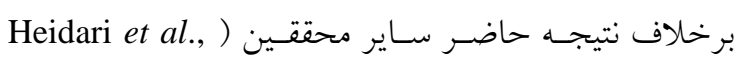
2006; Abdul Rehman Rashid et al., 2012; Faroog et (al., 2006; Rahim et al., 2006

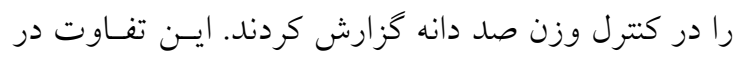
نتايج حاصل از تحقيق حاضر و ساير تحقيقات مسى توانــ

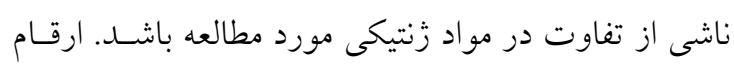

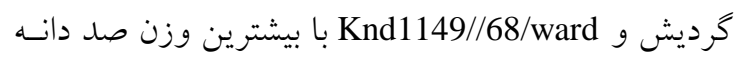

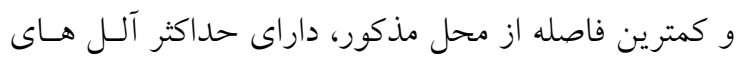

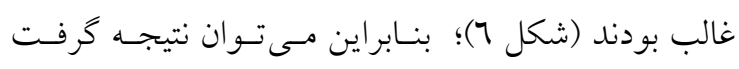

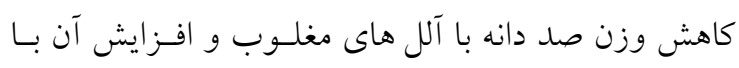
آللهاى غالب كنترل مىشود.

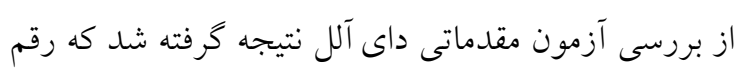

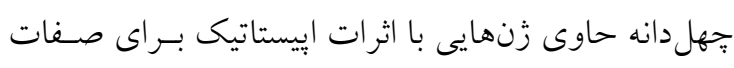

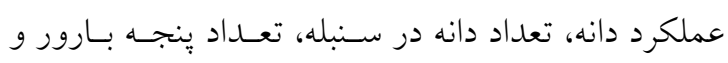

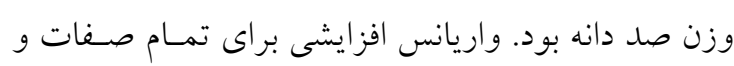

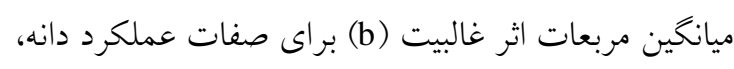

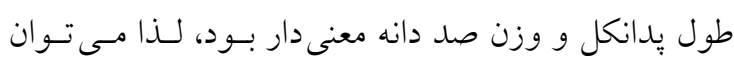

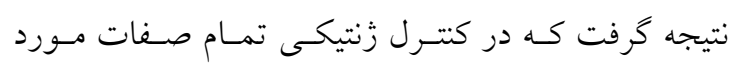

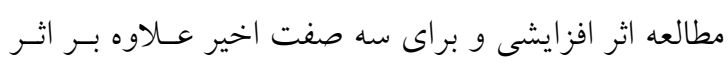

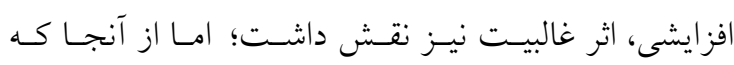

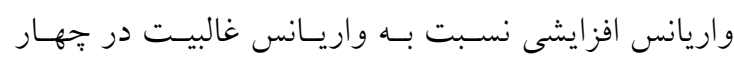

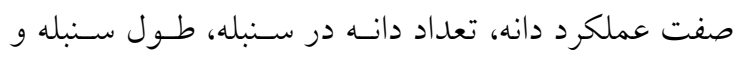




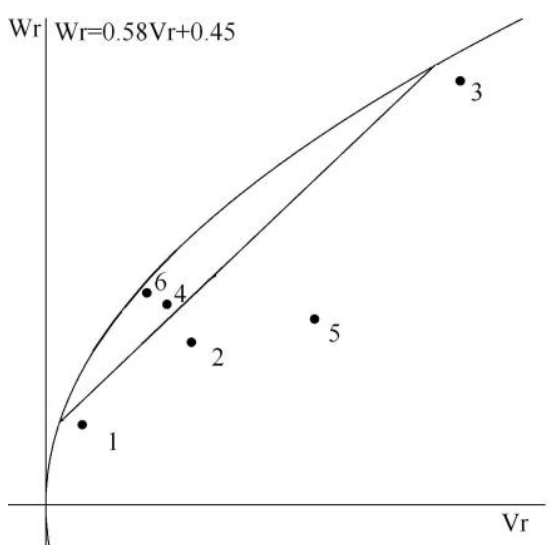

شكل ع- رخرسيون Wr بر روى Vr براى طول سنبله (1)

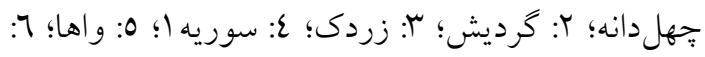

(Knd1149//68/ward

Figure 4. Regression of $\mathrm{Wr} / \mathrm{Vr}$ for spike length (1: Chehel daneh; 2: Gerdish; 3: Zardak; 4: Syrian-1; 5: Waha; 6: Knd1149//68/ward)

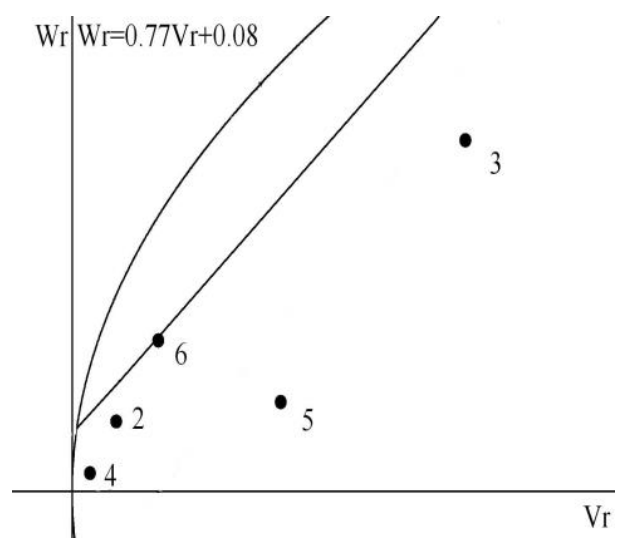

شكل T- ركرسيون Wr بر روى Vr براى وزن صد دانه (r:

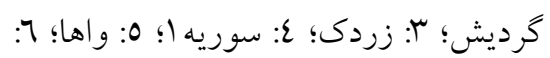

\section{(Knd1149//68/ward}

Figure 6. Regression of $\mathrm{Wr} / \mathrm{Vr}$ for hundred grain weight (1: Chehel daneh; 2: Gerdish; 3: Zardak; 4:

Syrian-1; 5: Waha; 6: Knd1149//68/ward)

بيشترين ميزان عملكرد (T/K/ ا گرم در بوته) و واها ×

جهل دانه نسبت به متوسط والدين هتروزيس نشان دادند

(دادهها درج نشدهاند) و در آنها ميزان عملكرد دانه از

متوسط عملكرد تمام زنوتيبها بيشتر بود، امكان

بهرهگيرى از اين تلاقىها جهت دستيابى به نتاجى با

عملكرد مناسب وجود دارد. از بين ارقام والدينى فوق،

عملكرد دانه در ارقام زردى، Knd1149//68/ward و و واها

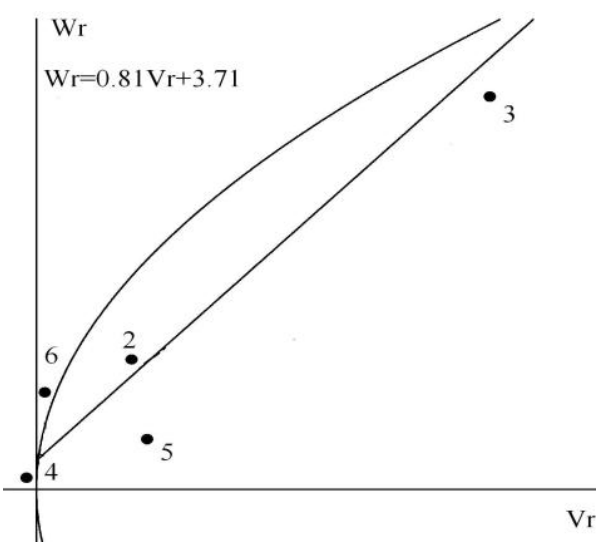

شكل r- رگرسيون Wr بر روى Vr براى تعداد دانه در سنبله

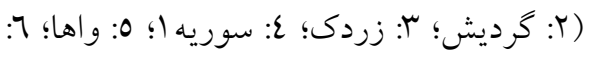

(Knd1149//68/ward

Figure 3. Regression of $\mathrm{Wr} / \mathrm{Vr}$ for number of grain per spike (1: Chehel daneh; 2: Gerdish; 3: Zardak; 4:

Syrian-1; 5: Waha; 6: Knd1149//68/ward)

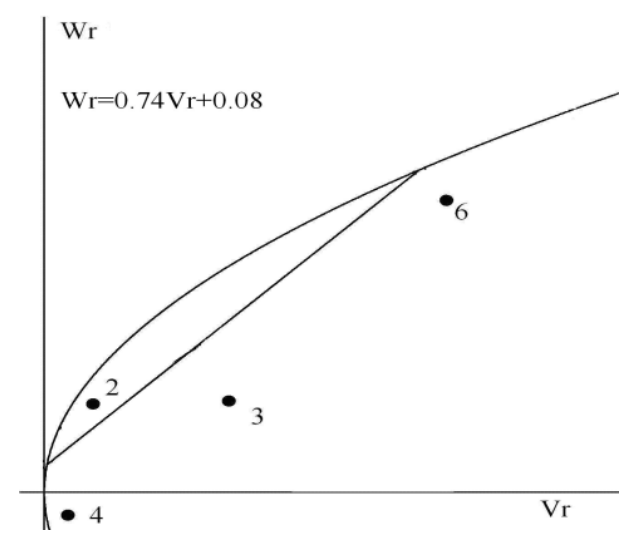

شكل 0-رخرسيون Wr بر روى Vr براى تعداد ينجه بارور

$$
\text { (ז: كرديش؛ "ז: زردك؛ ع: سوريه ا؛ 7: }
$$

(Knd1149//68/ward

Figure 5. Regression of $\mathrm{Wr} / \mathrm{Vr}$ for number of fertile tiller (1: Chehel daneh; 2: Gerdish; 3: Zardak; 4:

Syrian-1; 5: Waha; 6: Knd1149//68/ward)

براى تمام اين صفات در حدود ميانه قرار داشت، به نظر مىرسد افزايش اين صفات توسط تركيبى از آللهاى برى غالب و مغلوب كنترل گردد. رقم گرديش بومى استان اردبيل بوده و داراى تحمل مناسب نسبت به تنش سرما دارد (Nedjadsadeghi et al., 2014). با توجه به اينكه تلاقى هاى مستقيم و معكوس جهل دانه × زردك و زردى × واها و همجنين تلاقى Knd1149//68/ward × واها با 


$$
\begin{aligned}
& \text { توسط آللهاى مغلوب و براى جهلدانه توسط اثرات اثرات افزايشى در زرميلاسم تحت بررسى در اين يزوهش } \\
& \text { اييستاتيك كتترل مىشود. هم:جنين از آنجا كه هتروزيس اثر تجمعى در انتقال زنها به نسل بعد، مىتوان از طريق } \\
& \text { مشاهده شده براى عملكرد دانه ناشى از غالبيت جزء اينش در نسلهاى اوليه در راستاى اهداف افز } \\
& \text { است، امكان توليد لاينهاى هيبريدى كه فراتر از والدين اجفات عملكرد و إى عملكرد دانه در برنامه اصلاح }
\end{aligned}
$$

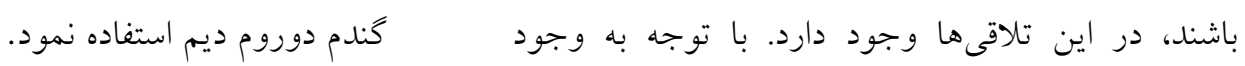

\section{References}

Abdul Rehman Rashid, M., Salam Khan, A. and Iftikha, R. (2012). Genetic studies for yield and yield related parameters in bread wheat. American-Eurasian Journal of Agricultural and Environmental Sciences, 12(12): 1579-1583.

Al-Hamdany, A.T.A. (2010). Genetic analysis of $\mathrm{F}_{2}$ Diallel crosses in durum wheat. Mesopotamia Journal of Agriculture, 38:77-84.

Chowdhry, M.A., Saeed, M.S., Khaliq, I. and Ahsan, M. (2005). Combining ability analysis for some polygenic traits in a $5 \times 5$ diallel cross of bread wheat (Triticum aestivum L.). Asian Journal of Plant Sciences, 4(4): 405-408.

Eqbal, M., Nabavi, A., Salmon, D.F., Yang, R.C. and Spaner, D. (2007). Simultaneous selection for early maturity, increased grain yield and elevated grain protein content in spring wheat. Plant Breeding, 126: 244-250.

FAO. (2013). FAO annual statistics reports. http://faostat.fao.org/site.

Faroog, J., Imran, H, Akhtar, S., Nausherwan, I.K. and Ghulam, A. (2006). Combining ability for yield and its components in bread wheat (Triticum aestivum L.). Journal of Agriculture and Social Sciences, 4: 207-211.

Griffing, B. (1956). Concept of general and specific combining ability in relation to diallel crossing systems. Australian Journal of Biology Science, 9: 463-493.

Habib, I. and Khan, A.S. (2003). Genetic model of some economic traits in bread wheat (Titicum aestivum L.). Asian Journal of Plant Sciences, 2: 1153-1154 (In Persian).

Hayman, B.I. (1954 a). The analysis of variance of diallel tables. Biometrics, 10: 235-244.

Hayman, B.I. (1954 b). The theory and analysis of diallel crosses. Genetics, 39: 789-809.

Heidari, B., Rezai, A.M. and Mirmohammadi Maibody, S.A.M. (2006). Diallel analysis for the estimation of genetic parameters for grain yield and grain yield components in bread wheat. Journal of Science and Technology of Agriculture and Natural Resources, 10: 121-139 (In Persian).

Jinks, J.L., and Hayman, B.I. (1953). The analysis of diallel crosses. Maize Genetics and Cooperation Newsletter, 27: 48-54.

Kearsey, M.L. and Pooni, H.S. (1996). The genetic analysis of quantitative traits. Chapman and Hall, London, UK.

Khan, A.S., Khan, M.K.R. and Khan, T.M. (2000). Genetic analysis of plant height, grain yield and other traits in wheat (Triticum aestivum L.). International Journal of Agriculture and Biology, 2: 129-132.

Lonc, W., Kadlubiec, W. and Strugala, J. (1993). Genetic determination of agronomy characters in F2 hybrids of winter wheat. Zeszyty Naukowe Akademii Rolniczej we Wroclawiu Rolnictwo, 223: 229-247.

Leng, Y. and Hong, D.L. (2004). Grain quality and genetic analysis of hybrids derived from different ecological types in Japonica rice (Oryza sativa L.). Rice Science, 11: 165-170. 
Mahmood, N. and Chowdhry, M.A. (2002). Ability of bread wheat genotypes to combine for high yield under varying sowing conditions. Journal of Plant Genetics and Breeding, 56: 119-125.

Malik, M.F.A., Iqbal, S. and Ali, S. (2005). Genetic behavior and analysis of quantitative traits in five wheat genotypes. Pakistan Journal Agricultural Resrarch, 1(4): 313-315.

Mann, M.S. and Sharma, S.N. (1995). Genetics of yield, harvest index and related components in durum wheat. Crop Improvement, 22: 38-44.

Mather, K. and Jinks, J.L. (1985). Biometrical genetics. Chapman and Hall, London, UK.

Mohammadi, S. and Khodambashi Emami, M. (2008). Graphical analysis for grain yield of wheat and its components using diallel crosses. Seed and Plant Improvement Journal, 24(3): 475-486 (In Persian).

Nedjadsadeghi, L., Maali Amiri, R., Zeynali Kkanghah, H., Sadeghzadeh, B. and Ramezanpour, S.S. (2014). Evaluation of some cold-induced responses in bread and durum wheat plants. New Genetic, 9 (3): 353-362 (In Persian).

Nazeer, W., Farooq, J., Tauseef, M., Ahmed, S., Khan, M.A., Mahmood, K., Hussain, A., Iqbal, M. and Nasrullah, H.M. (2011). Diallel analysis to study the genetic makeup of spike and yield contributing traits in wheat (Triticum aestivum L.). African Journal of Biotechnology, 10(63): 13735-13743.

Rahim, M.A., Salam, A., Saeed, A. and Shakeel, A. (2006). Combining ability for flag leaf area, yield and yield components in bread wheat. Journal of Agricultural Research, 44(3): 175-180.

Roy, D. (2000). Plant Breeding Analysis and Exploitation of Variation. Alpha Science International LTD, Oxford, UK.

Sadeghi, F. (2014). Estimation of genetic structure of yield and yield components in bread wheat (Triticum Aestivum L.) using diallele method. Journal of Crop Breeding, 6:101-113.

Sadeghi, F., Dehghani, H. Najafian, G. and Sarbourzeh Aghaei, M. (2013). Estimation of gene action and genetic parameters for bread making quality attributes in hexaploid wheat (Triticum aestivum L.). Seed and Plant Improvement Journal, 29:443- 465 (In Persian).

SAS. (2005). User's Guide. Ver. 8. SAS Institute Inc, Carolina, USA.

Sharma, R. (1998). Statistical and Biometrical Techniques in Plant Breeding. Publishers H.S. Poplai for New Age International Limited, New Delhi, IND.

Shi, C.H., Zhu, J., Zeng, R.C. and Chen, G.L. (1997). Genetic and heterosis analysis for cooking quality traits of Indica rice in different environments. Theoretical and Applied Genetic, 95: 294300.

Singh, H., Sharma, S.N. and Sain R.S. (2004). Combining ability for some quantitative characters in hexaploid wheat (Triticum aestivum L. em. Thell). Crop Science, 45: 68-72.

Singh, R.P. and Singh, S. (1992). Estimation of genetic parameters through generation means analysis in bread wheat. Indian Journal of Genetics and Plant Breeding, 52:369-375.

Srivastava, H.K. (2002). Nuclear and cytoplasmic diversity in manifestation of disease control and gene pool conservation for sustainable crop productivity. Journal of Sustainable Agriculture, 21: 47-72.

Ukai, Y. (2006). DIAL98. A package of progams for the analyses of a full and half diallel table with the methods by Hayman (1954), Griffing (1954) and others. Available from: http://lbm.ab.a.utokyo.ac.jp/ ukai/dial98.html.

Vanda, M. and Houshmand, S. (2011). Estimation of genetic structure of grain yield and related traits in durum wheat using diallel crossing. Iranian Journal of Crop Science, 13(1): 206-218. (In Persian).

Verma, O.P. and Srivastava, H.K. (2004). Genetic component and combining ability analyses in relation to heterosis for yield and associated traits using three diverse rice-growing ecosystems. Field Crop Research, 88: 91-102. 


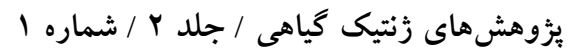

Weber, R. (1991). Diallel anlysis of useful traits of winter wheat. Zeszyty Naukowe Akademii Rolniczej we Wroclawiu Rolinctwo, 207: 199-210.

Zecevic, V., Knezevic, D., Pavlovic, M. and Micanovic, D. (1997). Genetic analysis of yield components in winter wheat. Genetika 29: 31-40. 


\title{
Estimation of Genetic Parameters of Morphological Traits in Rainfed Durum Wheat (Triticum turgidum L.) using Diallel Method
}

\section{Davoud Sadeghzadeh-Ahari ${ }^{1}$, Peyman Sharifi' ${ }^{2,}$, Rahmatollah Karimizadeh ${ }^{3}$ and Mohtasham Mohammadi ${ }^{3}$}

1- Assistant Professor, Dry Land Agricultural Research Institute, Maragheh, Iran

2- Assistant Professor, Department of Agronomy and Plant Breeding, Faculty of Agriculture, Islamic Azad University of Rasht, Rasht, Iran

3- Assistant Professor, Dry Land Agricultural Research Institute, Gachsaran, Iran

(Received: June 02, 2014 - Accepted: February 28, 2015)

\begin{abstract}
To estimate the genetic components and the mode of inheritance for some morphological traits, six rainfed durum wheat genotypes (Chehel daneh, Gerdish, Zardak, Syrian-1, Waha and Knd1149//68/ward) and their complete diallel progenies were grown in a randomized complete blocks design with two replications in 2005-06 cropping season in Maragheh Dryland Agricultural Research Station. Results of diallel analysis revealed that additive variance were important for inheritance of grain yield, number of grain per spike, spike length and number of fertile tiller than dominance variance. The positive value of ' $F$ ', indicated that there were excess of dominant alleles in comparison to recessive ones in the parents for all of the studied traits. The average degree of dominance $\left(\mathrm{H}_{1} / \mathrm{D}\right) 0.5$ showed partial dominance for grain yield, number of grain per spike, spike length, 100 grains weight and number of fertile tiller and over-dominance for peduncle length. Graphic analysis indicated that increase of grain yield, number of grain per spike, spike length, 100 grains weight and number of fertile tiller were under the control of combination of recessive and dominance alleles. Predominance of additive effects for grain yield demonstrated that breeding methods based on selection may be advantageous in improving of this trait. The highest value of this trait relevant to Gerdish (10.33 $\mathrm{g} / \mathrm{plant}$ ), therefore this genotype can be used as cross parent in breeding programs for receiving to lines with high yield and yield components. The cross of Waha $\times$ Knd1149//68/ward with high value of GY and GCA for this trait can be used as a suitable cross for hybrid production.
\end{abstract}

Keywords: Additive gene effects, Non-additive gene effects, Dominance, Durum wheat, Graphic analysis

\footnotetext{
* Corresponding Author, E-mail: peyman.sharifi@gmai.com
} 